\title{
DISTAL TUBULAR NECROSIS WITH LITTLE OR NO OLIGURIA
}

\author{
BY \\ SIMON SEVITT \\ From the Pathology Department and M.R.C. Burns Research Unit, Birmingham Accident Hospital
}

(RECEIVED FOR PUBLICATION SEPTEMBER 27, 1955)

The clinico-pathological syndrome of acute renal failure following abortion, incompatible blood transfusion, crush injuries, severe trauma, sulphonamide intoxication, and many other conditions including burns is now well known (Bratton, 1941 ; Dunn, Gillespie, and Niven, 1941 ; Bywaters and Beall, 1941 ; Bywaters and Dible, 1942 ; Lucké, 1946 ; Bull, Joekes, and Lowe, 1950 ; Bull and Dible, 1953). Clinically it is characterized by a short onset phase during which the flow of urine rapidly falls. Then follows the period of anuria or severe oliguria. This was defined by Bull as the excretion by an adult of not more than $300 \mathrm{ml}$. of urine per day and usually considerably less. This state may last up to a week or longer; uraemia develops and commonly proves fatal. Recovery is heralded by a period of diuresis during the early phase of which tubular function is seriously limited. By ordinary histological methods the kidneys show multiple, often discrete necroses of many distal tubules frequently associated with tubular blockage by haemoglobin or other casts. Rupture of tubules and dislocation of casts into the interstitial tissue and veins produce a peritubular and perivenous infiltration of inflammatory cells, tubulo-venous anastomoses, and thromboses. By microdissection of individual nephrons Oliver and his colleagues (Oliver, MacDowell, and Tracy, 1951; Oliver, 1953) have shown that the tubular necrosis is widespread and frequently involves the first convoluted tubule.

The purpose of this paper is to describe a number of subjects whose kidneys showed either these changes or their residue and in whom oliguria either did not occur or was transient or slight. With one exception all were severely burned. A few died before uraemia could develop, some became uraemic, and in others uraemia did not occur. Thus, in addition to the well-known uraemia-oliguria syndrome, uraemia may occur with an adequate flow of urine. This is important to recognize, because the patient's chance of survival has increased with the introduction of high-calorie, low-nitrogen feeding. The finding of one case of post-traumatic uraemia with little or no oliguria indicates that this form of renal failure is not restricted to burned patients. It will be shown that the difference between the uraemic and non-uraemic forms generally has a morphological basis, and that the tubular dysfunction in these uraemic subjects differs from that reported in the oliguric type of acute renal failure (Bull et al., 1950).

\section{Terminology}

The name "lower nephron nephrosis" introduced by Lucké is unsuitable because the tubular necrosis is said to be the essential morphological feature (Oliver et al., 1951 ; Bull and Dible, 1953). These authors had adopted "acute tubular necrosis" as the more suitable descriptive term. In this paper "distal tubular necrosis" (D.T.N.) is synonymous with Luckés lower nephron nephrosis, because D.T.N. is morphologically different from the cortical type of necrosis which also occurs in burned subjects (unpublished observations).

Distal tubular necrosis after burning varies in severity. The kidney may be diffusely affected and parts of the tubules of many nephrons may be necrosed. Alternatively the kidney may be focally involved, and relatively few tubules may be affected. To these main types the terms "diffuse" and "focal "D.T.N. are applied, and refer to the histological density of lesions; but in both the diffuse and focal kinds the individual tubules are commonly affected in a discrete or focal fashion. The involvement of many or few nephrons respectively is the main histological difference between the uraemic and non-uraemic forms now reported. 


\section{The Patients}

The present paper is concerned with 22 patients, 21 of whom were extensively burned, the other was an unusual case of post-traumatic uraemia. The burned subjects formed part of a renal histological analysis based on 86 fatally burned subjects which is to be reported later. In 35 of these there was either a focal or a diffuse distal tubular necrosis or the "healed" residue of a recent focal attack. Twelve rapidly became almost anuric and uraemia developed in those surviving four days or longer: in three others the urine flow was not known. The remaining 20 form the main basis of the present paper, but two other patients are included, a burned child on whom necropsy was refused and a post-traumatic case of uraemia, a man who fell $15 \mathrm{ft}$. off a ladder and in whom a large adrenal tumour became completely necrosed.

All necropsies were performed within 38 hours of death: 17 within 24 hours and eight within 12 hours.

\section{Routine Treatment of the Burned Patients}

The degree of haemoconcentration on admission and during the shock phase was estimated by serial haematocrit observations from which the amount of plasma lost from the circulation was calculated. In recent cases repeated blood volume studies were carried out by Dr. E. Topley. Such means guided the amount and speed of plasma transfusion by which oligaemia was combated. Transfusion with plasma was begun soon after admission, usually within a few hours of burning, and was continued for about two days. Some patients were also transfused with blood at this stage, but in other patients blood transfusion was delayed for a week or longer. Other intravenous fluids (dextran, glucose, saline) were also sometimes transfused. Oral fluids, usually sweetened fruit juice, glucose-water, or sodium lactate, were also given when vomiting was absent. Two or three days later, feeding by an egg-milk mixture was begun and was continued until an adequate diet could be taken about 10 to 14 days after burning. Skin grafting was usually carried out after two or three weeks and blood transfusion was given during each operation. The burns were first dressed at the end of the shock phase when penicillin cream and/or other local antibiotics were applied to prevent or control infection. Systemic therapy with penicillin, aureomycin, polymyxin, or erythromycin, or a combination, was introduced when infective complications arose.

\section{Classification}

The patients may be divided into two groups.

Group 1.-Group 1 consists of one injured and seven burned patients none of whom was considered to have been oliguric. Each patient developed significant azotaemia and uraemia played a major role in six.

Group 2.-Group 2 consists of 14 burned patients none of whom was considered to have been oliguric. In eight significant azotaemia did not occur and in the others uraemia was not suspected.

\section{Group 1}

Details of the patients* are given in Table I. One of the burned patients was a girl of 5 years, two others were girls of 14 and 15 years, and the remainder were men 20 to 44 years old. The burns extended over $35 \%$ to $80 \%$ of the body area in the different patients (mean area burned was $58 \%$ ). Two patients who survived only two and two and a half days and died with pre-uraemic azotaemia are included, Case 1 because the histological changes in the kidneys may be the earlier stages of those who survive longer and become uraemic, and Case 2 because it had special features. The other patients, including the case of post-traumatic uraemia, survived between six and 21 days.

Azotaemia.-Most of the serum or blood urea levels (C.S.F. in Case 7) are given in Table II. In Case 1, a patient who survived only two days, the level of $80 \mathrm{mg} . \%$ is taken to represent a preuraemic azotaemia. The blood urea in Case 2 rose from $80 \mathrm{mg} . \%$ at 12 hours after burning to 190 $\mathrm{mg} . \%$ on the day of his death two days later. * A further example, who was under the care of Mr. R. L. G.
Dawson, at Mount Vernon Hospital Plastic Centre, is reported. A woman of 35 years with $40 \%$ burns survived 12 days. She was admitted haemoconcentrated, was at first transfused with plasma and glucose solution and later with blood. About $500 \mathrm{ml}$. urine was passed during the first 12 hours; during the second 12 hours oliguria was transient and $150 \mathrm{ml}$. urine passed; during the next four days between 1 and 2 litres daily were passed and thereafter the urine volumes varied between 0.7 and 1.0 litre a day. Haemoglobinuria was not found. Uraemia with considerable azotaemia occurred; the blood urea was 232 and $211 \mathrm{mg}$. \% on days 7 and 8 and rose to 423 and $413 \mathrm{mg}$. \%. The specific gravity of the urine was 1010 on day 6 . The ratio of U B urea was only 5 to 1 and the standard urea clearance was only $5.6 \%$ of average normal. Jaundice and hyperglycaemia occurred. The serum potassium and sodium values were normal or slightly raised and there was no acidaemia. She died in uraemia with bronchopneumonia.

In the kidneys a histologically severe form of diffuse distal tubular necrosis was seen, viz., frequent rupture of distal tubules with extrusion of casts and of thrombi in the venules; atypical or bizarre regeneration of many Henle and distal convoluted tubules; granular eosinophilic (benzidine-negative) and colloid casts in some distal and collecting tubules; many characteristically located collections of lymphoid and other inflammatory cells, considerable oedema of the cortex and pyramid, etc. Prussian blue staining showed a thin, irregular deposit of iron pigment on the free surfaces of the epithelium,
mainly of the distal tubules. 
TABLE I

DETAILS OF THE PATIENTS

\begin{tabular}{|c|c|c|c|c|c|c|c|c|}
\hline Group & $\begin{array}{l}\text { Case } \\
\text { No. }\end{array}$ & $\mathrm{Ag}$ & & $\begin{array}{c}\text { Area } \\
\text { Burned } \\
(\%)\end{array}$ & $\begin{array}{c}\text { Survival } \\
\text { Period }\end{array}$ & $\begin{array}{l}\text { Known } \\
\text { Haemo- } \\
\text { globinuria }\end{array}$ & Renal Histology & $\begin{array}{c}\text { Cause of } \\
\text { Death and Other } \\
\text { Significant Features }\end{array}$ \\
\hline 1 & $\begin{array}{l}1 \\
2 \\
\\
3 \\
4 \\
5 \\
6 \\
7 \\
\\
8\end{array}$ & $\begin{array}{r}5 \\
20 \\
\\
15 \\
43 \\
44 \\
14 \\
31 \\
40\end{array}$ & $\begin{array}{l}\mathbf{F} \\
\mathbf{M} \\
\mathbf{F} \\
\mathbf{M} \\
\mathbf{M} \\
\mathrm{F} \\
\mathrm{M}\end{array}$ & $\begin{array}{r}75 \\
35 \\
80 \\
65 \\
44 \\
60 \\
50 \\
\text { Trauma }\end{array}$ & 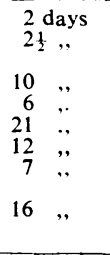 & $\begin{array}{l}+- \\
+ \\
+ \\
+-\end{array}$ & $\begin{array}{l}\text { Early diffuse D.T.N. } \\
\text { Cortico-tubular degeneration } \\
\text { with focal " healed" D.T.N. } \\
\text { Diffuse D.T.N. } \\
\quad, ", \\
\text { Necropsy"refused } \\
\text { Cortico-tubular degeneration } \\
\text { with focal D.T.N. } \\
\text { Diffuse D.T.N. }\end{array}$ & $\begin{array}{l}\text { Pulmonary atelectasis } \\
\text { Acute haemolytic jaundice. Inci- } \\
\text { pient uraemia } \\
\text { Uraemia } \\
\text { Uraemia. Pulmonary embolism } \\
\text { Uraemia } \\
\quad, \\
\text { Uraemia. Necrosis of large } \\
\text { adrenal adenoma, etc. }\end{array}$ \\
\hline 2 & $\begin{array}{l}99 \\
10 \\
11 \\
12 \\
13 \\
14 \\
15 \\
16 \\
17 \\
18 \\
19 \\
20 \\
21 \\
22\end{array}$ & $\begin{array}{r}4 \\
4 \\
27 \\
7 \\
5 \\
4 \\
5 \\
6 \\
6 \\
3 \\
2 \\
6 \\
10 \\
5\end{array}$ & $\begin{array}{l}\mathbf{F} \\
\mathbf{F} \\
\mathbf{M} \\
\mathrm{F} \\
\mathbf{M} \\
\mathbf{M} \\
\mathbf{M} \\
\mathbf{M} \\
\mathrm{F} \\
\mathrm{F} \\
\mathbf{M} \\
\mathrm{F} \\
\mathbf{F} \\
\mathrm{F}\end{array}$ & $\begin{array}{l}60 \\
45 \\
70 \\
65 \\
45 \\
28 \\
47 \\
63 \\
50 \\
45 \\
27 \\
50 \\
65 \\
70\end{array}$ & 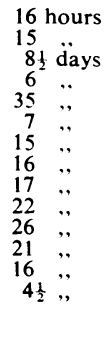 & + transient & 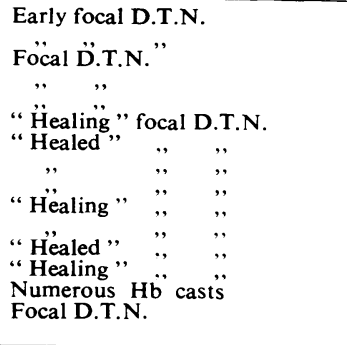 & $\begin{array}{l}\text { Pulmonary oedema } \\
\text { Pulmonary atelectasis } \\
\text { Bronchopneumonia } \\
\text { Acute medullary coning } \\
\text { Bronchopneumonia } \\
\text { Septicaemia } \\
\text { Purulent bronchiolitis } \\
\text { Pulmonary infarct } \\
\text { Septicaemia. Agranulocytosis } \\
\text { Pyaemic bronchopneumonia } \\
\text { Curling's ulcer. Diarrhoea } \\
\text { Haematemesis. Curling's ulcer } \\
\text { Purulent bronchiolitis }\end{array}$ \\
\hline
\end{tabular}

Area burned, $\%$ of the total surface area of the patient. $?=$ Associated with a true haematuria (see text). D.T.N. $=$ Distal tubular necrosis: for description of various stages see text.

This is considered an incipient uraemia. In the other patients blood urea estimations were not made before the sixth to the ninth day of illness because of the clinical difficulty in suspecting uraemia (vide infra). Presumably because of this delay the first blood urea observations were always high, the levels varying between 280 and $357 \mathrm{mg}$. \% in the different subjects. The progres- sive elevations to these levels are not known and the rate of development of the azotaemia can only be surmised. Subsequent observations in Cases $5, \stackrel{\mathbb{Q}}{\Omega}$ 6 , and 8 confirmed the high blood urea levels. $\overrightarrow{\vec{P}}$ Cessation of feeding with protein after the high $\frac{\circ}{3}$ urea levels had been discovered may have been $\bar{T}$ responsible for preventing further rises in Cases 5 훙 and 8 .

TABLE II

DAILY URINARY OUTPUT AND BLOOD, SERUM, OR C.S.F. UREA LEVELS IN SIX CASES OF ACUTE URAEMIA WITH LITTLE OR NO OLIGURIA (GROUP 1)

\begin{tabular}{|c|c|c|c|c|c|c|c|c|c|c|c|c|c|c|}
\hline \multirow[t]{2}{*}{ Day } & \multicolumn{2}{|c|}{$\begin{array}{c}\text { Classical } \\
\text { Anuric Type } \\
\text { M. } 24 \text { yr., } \\
75 \% \text { Burns }\end{array}$} & \multicolumn{2}{|c|}{ Case 3} & \multicolumn{2}{|c|}{ Case 4} & \multicolumn{2}{|c|}{ Case 5} & \multicolumn{2}{|c|}{ Case 6} & \multicolumn{2}{|c|}{ Case 7} & \multicolumn{2}{|c|}{ Case 8} \\
\hline & $\begin{array}{l}\text { Urine } \\
\text { (ml.) }\end{array}$ & $\begin{array}{c}\begin{array}{c}\text { Blood } \\
\text { Urea } \\
(\mathrm{mg} .\end{array} \\
100 \mathrm{ml} .)\end{array}$ & $\begin{array}{l}\text { Urine } \\
(\mathrm{ml} .)\end{array}$ & $\begin{array}{c}\text { Blood } \\
\text { Urea } \\
\text { (mg. } \\
100 \mathrm{ml} .)\end{array}$ & $\begin{array}{l}\text { Urine } \\
\text { (ml.) }\end{array}$ & $\begin{array}{c}\text { Serum } \\
\text { Urea } \\
(\mathrm{mg} . \\
100 \mathrm{ml} .)\end{array}$ & $\begin{array}{l}\text { Urine } \\
\text { (ml.) }\end{array}$ & $\begin{array}{c}\begin{array}{c}\text { Blood } \\
\text { Urea } \\
(\mathrm{mg} . \\
100 \mathrm{ml} .)\end{array} \\
\end{array}$ & $\begin{array}{l}\text { Urine } \\
\text { (ml.) }\end{array}$ & $\begin{array}{c}\text { Blood } \\
\text { Urea } \\
(\mathrm{mg} . \\
100 \mathrm{ml} .)\end{array}$ & $\begin{array}{l}\text { Urine } \\
\text { (ml.) }\end{array}$ & $\begin{array}{l}\text { C.S.F. } \\
\text { Urea } \\
\text { (mg. } \\
100 \mathrm{ml} .)\end{array}$ & $\begin{array}{l}\text { Urine } \\
\text { (ml.) }\end{array}$ & $\begin{array}{l}\text { Blood } \\
\text { Urea } \\
\text { (mg. } \\
100 \mathrm{ml} .)\end{array}$ \\
\hline $\begin{array}{r}1 \\
2 \\
3 \\
4 \\
5 \\
6 \\
7 \\
8 \\
9 \\
10 \\
12 \\
14 \\
16 \\
18 \\
20\end{array}$ & $\begin{array}{r}168 \\
20 \\
0 \\
0 \\
0\end{array}$ & 284 & $\begin{array}{l}720++ \\
325++ \\
+++ \\
734++ \\
1,372+ \\
2,436 \\
2,950 \\
1,300 \\
1,000 \\
1,460\end{array}$ & 296 & $\begin{array}{r}685 \\
1,800 \\
400 \\
570 \\
413 \\
\text { Died }\end{array}$ & 357 & $\begin{array}{r}360 \\
990 \\
360 \\
630 \\
930 \\
1,080 \\
580 \\
2,400 \\
1,870 \\
980 \\
1,850 \\
2,050 \\
1,382 \\
900\end{array}$ & $\begin{array}{l}280 \\
271 \\
\\
232 \\
236 \\
206 \\
212\end{array}$ & $\begin{array}{c}830 \\
1,650 \\
1,300 \\
2,020 \\
880+ \\
1,000+ \\
740+ \\
+++ \\
750+ \\
1,590 \\
1,450+\end{array}$ & $\begin{array}{l}280 \\
276\end{array}$ & $\begin{array}{c}1,130 \\
875+ \\
360+ \\
740+ \\
800+ \\
477+\end{array}$ & 320 & $\begin{array}{c}\text { ? small } \\
\text { volume } \\
900 \\
1,300 \\
3,200 \\
2,100 \\
2,700 \\
2,300 \\
2,000 \\
2,200 \\
2,600 \\
2,500+ \\
2,100 \\
1,900\end{array}$ & $\begin{array}{l}290 \\
320 \\
320 \\
194 \\
274\end{array}$ \\
\hline
\end{tabular}

,,$+++++=$ Degrees of bed-wetting. 
Urine Flow.-The daily volumes of the urine passed by Cases 3 to 8 are given in Table II, where they can be compared with the volumes passed by one burned patient who developed the classical anuric type of acute renal failure. Case 1, a girl, who was only 5 years old, passed $790 \mathrm{ml}$. of urine on the first day and $350 \mathrm{ml}$. on the second day. Although the urinary output fell it was adequate for a child of her age. Case 2 passed 900, 820, and $640 \mathrm{ml}$. on successive days. Accurate measurements in three other patients were spoiled by bedwetting, but even the volumes which were measured were not oliguric. In Case 3 the urinary excretion during the first 48 hours was erratic and irregular, but the volumes recorded, which were 720,325 , and $734 \mathrm{ml}$. on the first, second, and fourth days after burning, do not indicate a sustained oliguria. A diuresis of 2 to 3 litres daily occurred on the sixth and seventh days; thereafter the urine flow was over 1 litre per day. The urinary output in Case 4 was $685,1,800,400,570$, and $413 \mathrm{ml}$. on successive days. This flow was inadequate, but was not considered oliguric. Case 5 passed less urine in the first seven days than he did subsequently, but only on the first and third days did the output of $360 \mathrm{ml}$. approach Bull's oliguric level. In Case 6 the urinary output, which varied from $740 \mathrm{ml}$. or more to 2 litres a day, was adequate throughout. The urinary flow in Case 7 was adequate on the first, second, fourth, and fifth days ( 740 to $1,130 \mathrm{ml}$.), was at least $360 \mathrm{ml}$. on the third day, and it may have fallen before he died. In the patient with post-traumatic uraemia (Case 8) oliguria was probable on the day of injury, but the volume passed is not known. Thereafter the daily excretion was normal and at times polyuric.

Therefore if oliguria did occur in any patient it was slight or transient.

Haemoconcentration and Fluid Intake during Shock Phase.-The burned patients were haemoconcentrated and oligaemic at least during the early part of the shock phase and the highest haematocrit values during this period were : Case $1,47 \%$; Case 2, $67 \%$; Case 3, $54 \%$; Case 4, $57 \%$; Case $5,57 \%$; Case $6,52 \%$; and Case 7 , $54 \%$. They were energetically transfused with plasma; sometimes blood or glucose or saline was also given and in addition oral fluids when vomiting did not prohibit them. Transfusion was generally more rapid during the first eight hours than subsequently and during this period the following total volumes of fluid were given : Case 1, 2.8 (1.8 plasma, 0.2 blood) ; Case 2, 1.5 plasma ; Case 3, 2.1 plasma; Case 4, 5.0 (4.2 plasma); Case 5, 5.0 (4.2 plasma) ; Case 6, 4.8 (3.2 plasma,
1.2 blood), and Case 7, 4.0 (2.0 plasma, 1.5 blood) litres. The total volumes of oral and intravenous fluids given during the shock phase (over a period of 48 hours except in Cases 4 and 5 , in which transfusion was stopped at 24 hours) were : Case 1, 8.7 (4.0 plasma, 0.7 blood) ; Case 2, 14.6 (8.0 plasma, 3.8 blood); Case 3, 11.6 (7.0 plasma, 0.5 blood); Case 4, 10.6 (6.3 plasma); Case 5, 10.4 (6.3 plasma) ; Case 6, 12.2 (7.3 plasma, 1.2 blood) ; and Case 7, 10.7 (6.5 plasma, 1.5 blood) litres.

Case 8 was given 4 litres of fluid during the first 24 hours, including 1 litre of blood.

Haemoglobinuria.-In five of the seven burned patients haemoglobinuria was known to occur. In the others (Cases 5 and 7) it was not recorded and if present was probably slight or transient. Haemoglobinuria occurred early, within hours of burning, and was associated with haemolysis in the plasma. In at least three of the patients the urine was deeply red for a day or longer.

Urinary Casts.-Numerous brown pigmented granular casts were present in the urinary deposits of all the patients at least on the first to the third days. In Case 4 they were still found on the sixth day after burning.

Clinical Uraemia.-Severely burned patients who survive the shock phase and who do not develop uraemia are frequently ill. Vomiting, if present, often continues for some days, tachycardia is usual, pyrexia is common, and often the mental state is disturbed. As a consequence the significance of symptoms due to incipient uraemia may be overlooked. Thus uraemia was not suspected until the end of the first week or later in those who survived a longer period. Symptoms of uraemia or consistent with uraemia were then present. Case 3 became restless, noisy, and irrational from about the third or fourth day, vomiting was troublesome, and she developed hiccups later. Case 4 also developed hiccups, became dyspnoeic, drowsy, and lapsed into coma. The general condition of Case 5 worsened after the first week when he became weak and drowsy. Case 6 remained in a fair general condition until the sixth day; thereafter she became weaker, hyperventilation with acidaemia ocurred, she became drowsy and finally comatose. During the last two or three days of life of Case 7 the symptoms of hiccups, retching, and vomiting were consistent with uraemia. Vomiting during the first few days of Case 8 was followed later by diarrhoea and abdominal distension. By the sixth day he was very ill, the tongue was furred and cracked, hyperventilation due to acidaemia 
appeared, he became thin, appeared dehydrated, and was mentally disorientated.

Even though none of the present patients survived, it is important to diagnose the uraemic state at an early stage, because the patient's chance of survival has probably increased with the introduction of high-calorie, low-nitrogen feeding.

Causes of Death.-Uraemia played a major part in the deaths of six patients (Cases 3 to 8), but one of them (Case 4) died suddenly from pulmonary embolism. Case 1 died in acute respiratory failure from pulmonary atelectasis. Acute haemolytic jaundice and incipient uraemia were probably responsible for the death of Case 2 .

Renal Function.-The findings are set out in Table IV. Urine urea estimations were carried out on one or more occasions in four patients (Cases 4 to 6 and 8 ) and urea clearance values were calculated from the 24-hour volumes of urine and the blood or serum urea level. In each case the ratio of the urine urea to the blood or serum urea was low, the values varying only from 2 to 6 in the first tests. The urea clearances were all significantly reduced, markedly in Case 4, in which the value was only $2.6 \%$ of average normal, and in the remainder significantly low values, 13 to $14 \%$ of normal, were obtained in the earlier tests. Subsequent tests showed little or no improvement, the values rising to only 15 to $18 \%$ of normal.

In two of these patients the concentration of the urine was repeatedly tested : the S.G. was fixed between 1010 and 1014, and in one patient the osmolarity, which ranged only from 330 to 435 m.osmols per litre, was little more than that of a plasma filtrate.

Sodium and chloride estimations of the serum $\frac{\bar{p}}{\frac{5}{a}}$ (S) and urine (U) in three patients indicated con- $\stackrel{\mathbb{\perp}}{\Omega}$ siderable tubular power to reabsorb these ions, particularly in Cases 5 and 6 . Low urinary values $\vec{P}$ of sodium and chloride were associated with normal or raised values in the serum. The $S / U \vec{\omega}$ ratios as a consequence were high. In Case $5 \stackrel{\text { S }}{\text {. }}$ this ratio varied from 35 to as much as 110 foro sodium: in Case 6 the $\mathrm{S} / \mathrm{U}$ for sodium ranged. from 15 to 30 and varied between 5 and 11 for. chloride; in Case 8 the ratios for sodium and $\vec{N}$ chloride were 6 and 5 respectively.

Terminal glycosuria consistent with severe tubular dysfunction occurred in Cases 1 and 7. In $\mathbb{D}$ the former the blood glucose was determined and found to be normal $(120 \mathrm{mg}$. \%).

Serum Biochemistry.-Definite hyperpotass- $\vec{\varphi}$ aemia was found in Cases 5, 6, and 8, with serum potassium values of $27.3,33$, and $23.4 \mathrm{mg}$.\% respectively, and a high normal level of 19.8 to $20 \mathrm{mg}$. \% was obtained in Case 8 . The serum sodium values were moderately or definitely raised in two patients $\left(380 \mathrm{mg} . \%\right.$ in Case $5,325-350 \frac{\circ}{\odot}$ mg. $\%$ in Case 8 ), and abnormally high serum $\cong$ chloride levels were found in Cases 6 and 8 (660) $\overrightarrow{\overrightarrow{0}}$ and $686-713 \mathrm{mg} . \%$ ). Low serum bicarbonate 3 values, presumably the result of acidaemia, were?

TABLE IV

RENAL FUNCTION

\begin{tabular}{|c|c|c|c|c|c|c|c|c|}
\hline \multirow{2}{*}{$\begin{array}{l}\text { Case } \\
\text { No. }\end{array}$} & \multicolumn{2}{|c|}{ Urine Concentration } & \multicolumn{3}{|c|}{ Urea } & \multirow{2}{*}{$\begin{array}{l}\mathrm{Na} \\
\mathrm{S} \mathrm{U}+\end{array}$} & \multirow{2}{*}{$\begin{array}{l}\mathrm{Cl} \\
\mathrm{S} \mathrm{U}\end{array}$} & \multirow{2}{*}{$\mathrm{US}_{+}^{\mathbf{K}}$} \\
\hline & $\begin{array}{l}\text { Specific } \\
\text { Gravity }\end{array}$ & $\begin{array}{c}\text { m.-Osmols } \\
\text { per Litre }\end{array}$ & $\begin{array}{l}\text { Blood or Serum } \\
(\mathrm{mg} . \%)\end{array}$ & U'S & $\begin{array}{c}\text { Clearance } \\
(\%)\end{array}$ & & & \\
\hline $\begin{array}{c}\text { Group } 1 \\
4 \\
5 \\
6 \\
8 \\
\end{array}$ & $\begin{array}{l}1010-14 \\
1010-12 \\
\end{array}$ & $330-435$ & $\begin{array}{l}357 \\
280 \\
280 \\
320 \\
\end{array}$ & $\begin{array}{c}2 \\
6-10 \\
7 \\
6 \\
\end{array}$ & $\begin{array}{l}2 \cdot 6 \\
13-18 \\
13-15 \\
14-15 \\
\end{array}$ & $\begin{array}{c}35-110 \\
15-30 \\
6\end{array}$ & $\begin{array}{c}5-11 \\
5\end{array}$ & $\begin{array}{l}7 \\
5\end{array}$ \\
\hline $\begin{array}{c}\text { Group } 2 \\
14 \\
15 \\
16 \\
17 \\
20 \\
21 \\
22\end{array}$ & $\begin{array}{c}1012^{*} \\
1016-22 \\
1004-22 \\
1010-14\end{array}$ & $\begin{array}{l}239-888 \\
284-978 \\
344-876 \\
258-350\end{array}$ & $\begin{array}{c}26-55 \\
40-55 \\
40-55 \\
43-61 \\
39-58 \\
58\end{array}$ & $\begin{array}{c}28-53 \\
22-30 \\
36-61 \\
35-40 \\
20-33 \\
16\end{array}$ & $\begin{array}{l}30-85 \\
40-50 \\
45-120 \\
\\
80-100 \\
40-41 \\
60-37\end{array}$ & & & \\
\hline
\end{tabular}

* One specimen only examined.

(1) The highest blood or serum urea levels are given for Cases 4 to 8: highest and lowest values are given in the other cases. (1) The highest blood or serum urea levels are given for Cases 4 to 8 : highest and lowest values are given in the other cases.
(2) $+\mathrm{U} S$ is the ratio of the concentration in the urine to that in the serum or blood for urea and the urine to serum ratio for potassium $\bar{B}$
\& $\mathrm{U}$ is the opposite ratio for sodium and chloride.

(3) Urea clearance $\%$ is based either on the standard clearance $\frac{U \sqrt{ }}{B}$ where $100 \%=54$ ml. of blood per minute, or the maximum clearance्छे $\underline{\mathrm{UV}}$ where $100 \%=75 \mathrm{ml}$. of blood per minute. Values in children are corrected for kidney weight by multiplying the urine volume by the average weight of normal adult kidneys $(14 \mathrm{oz}$.) and dividing by the weight of the patient's kidneys. 
also detected in these two patients (31 and 35 to 44 volumes $\mathrm{CO}_{2} \%$ respectively). However, these changes do not necessarily reflect renal failure, since they are not uncommon in other severely burned patients and are at least partly related to the intake of sodium, potassium, and other ions.

\section{The Kidneys}

The renal features of Cases 2 and 7 are in special categories and will be considered later. Necropsy was refused in Case 6.

Early Diffuse Distal Tubular Necrosis.-Case 1, which survived only two days, was included in the series partly because the histological findings may represent the early stage of those who survive longer. Her kidneys portrayed what may be considered to be the early form of diffuse distal tubular necrosis. Numerous haemoglobin casts of different types-amorphous, coarsely and finely granular-occupied the lumina of many collecting and distal secretory tubules and distended many of them (Fig. 1). Some casts contained desquamated epithelial cells. Casts were also present in the cortex, mainly in the ascending and second convoluted tubules. Many tubules were focally thinned and necrotic, particularly where the epithelium was compressed by casts. The glomerular capsules contained an abundance of coarse eosinophilic granules; the epithelium of the first convoluted tubules was swollen and they contained much albuminous debris. In many areas many of the glomerular tufts were bloodless. An occassional small focus of inflammatory cells was already to be seen in the boundary zone of the cortex.

Later Diffuse Distal Tubular Necrosis.-The kidneys of Cases $3,4,5$, and 8 were swollen and enlarged, together weighing as much as $19 \mathrm{oz}$. in Case 4. In the last three subjects the cortices were widened and the outlines were hazy (Fig. 2), but pallor was evident only in Case 4. The renal parenchyma was often softer than usual, particularly in Case 5, and in the kidneys of two patients (Cases 5 and 8 ) minute, whitish-grey foci were visible particularly in the bases of the pyramids.

Histology.-In these patients the changes were those of a diffuse distal tubular necrosis in a later developmental phase. Casts and tubular necrosis
FIGS. 1 to 8.-Diffuse distal tubular necrosis.

Fig. 1.-Many Henle tubules in the boundary zone of the cortex contain haemoglobin casts and parts of the tubular epithelium are thinned and necrotic. Case 1, haematoxylin and eosin, $\times 380$.

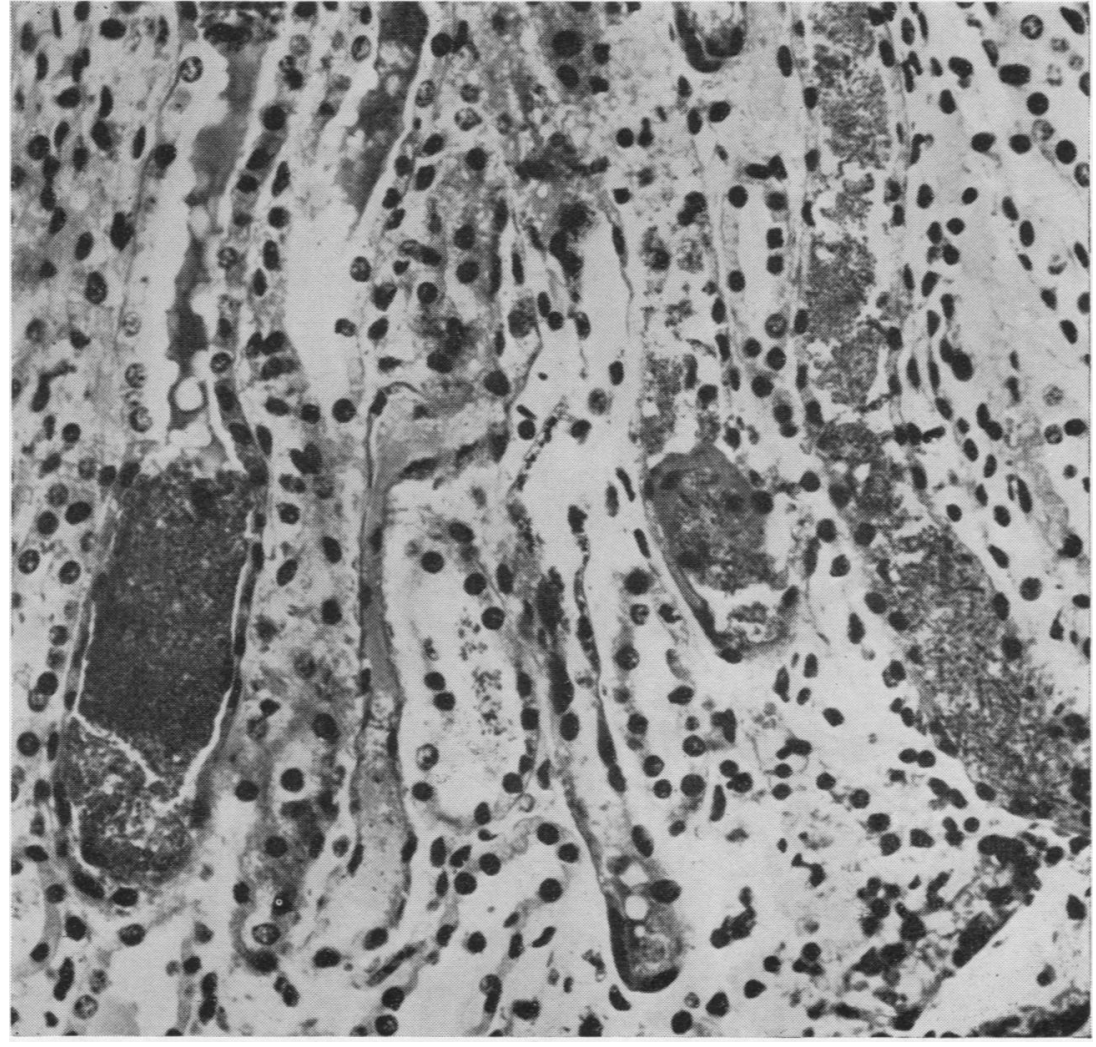




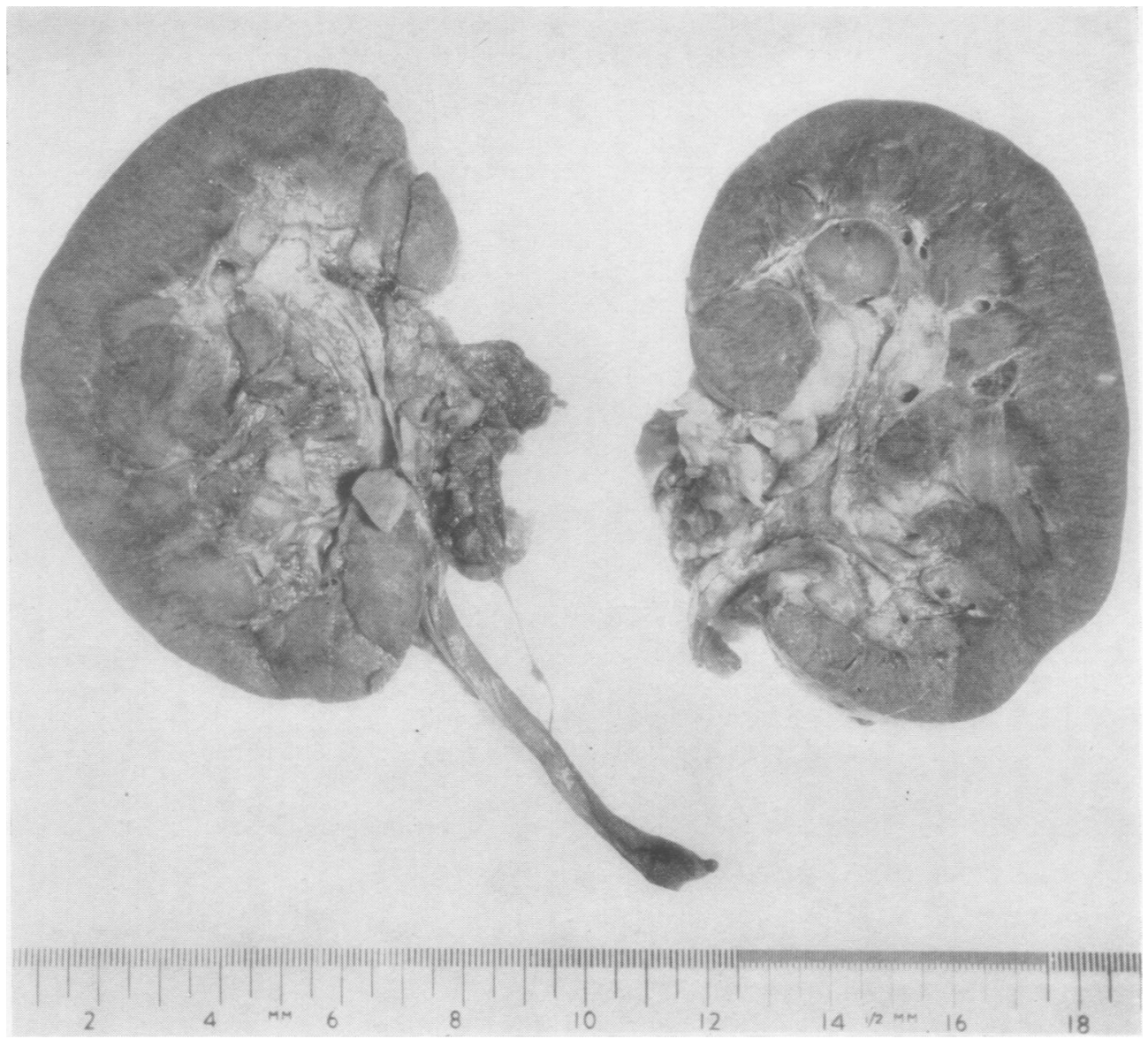

Fig. 2

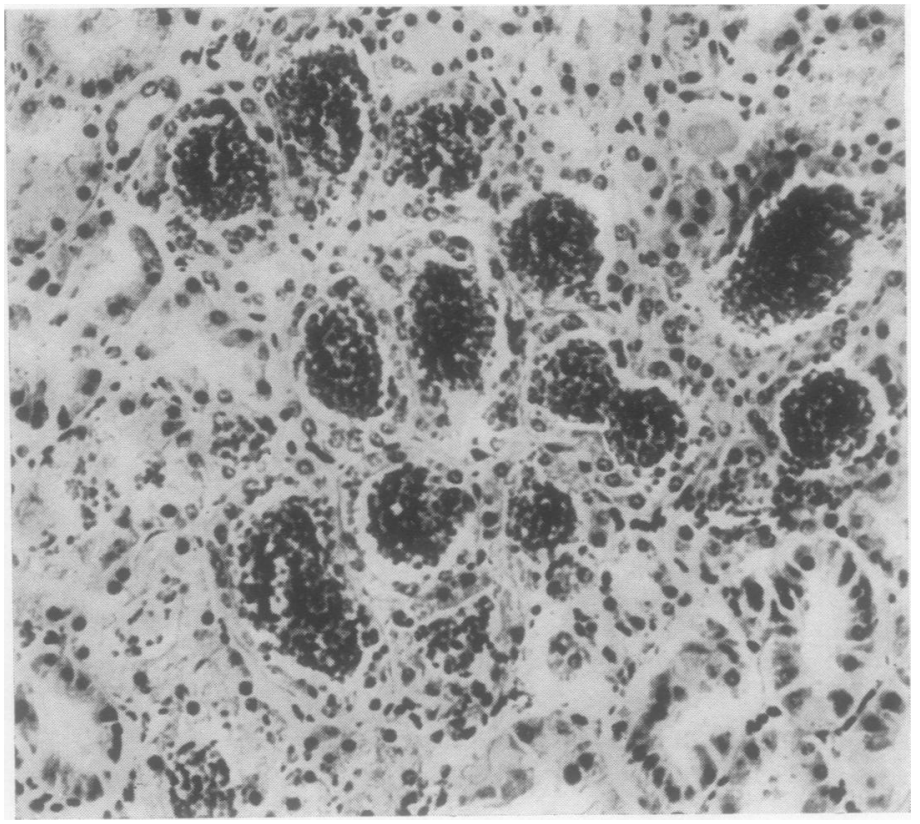

FIG. 2.-The kidneys of Case 5. The cortices o are broadened, the markings are indistinct $N$ and tiny whitish foci are present.

Fig. 3.-Many ascending Henle tubules are distended by granular haemoglobin casts. 0 Cross section at boundary zone. Case $3, \frac{\mathrm{C}}{\mathrm{C}}$ haematoxylin and eosin, 110. 


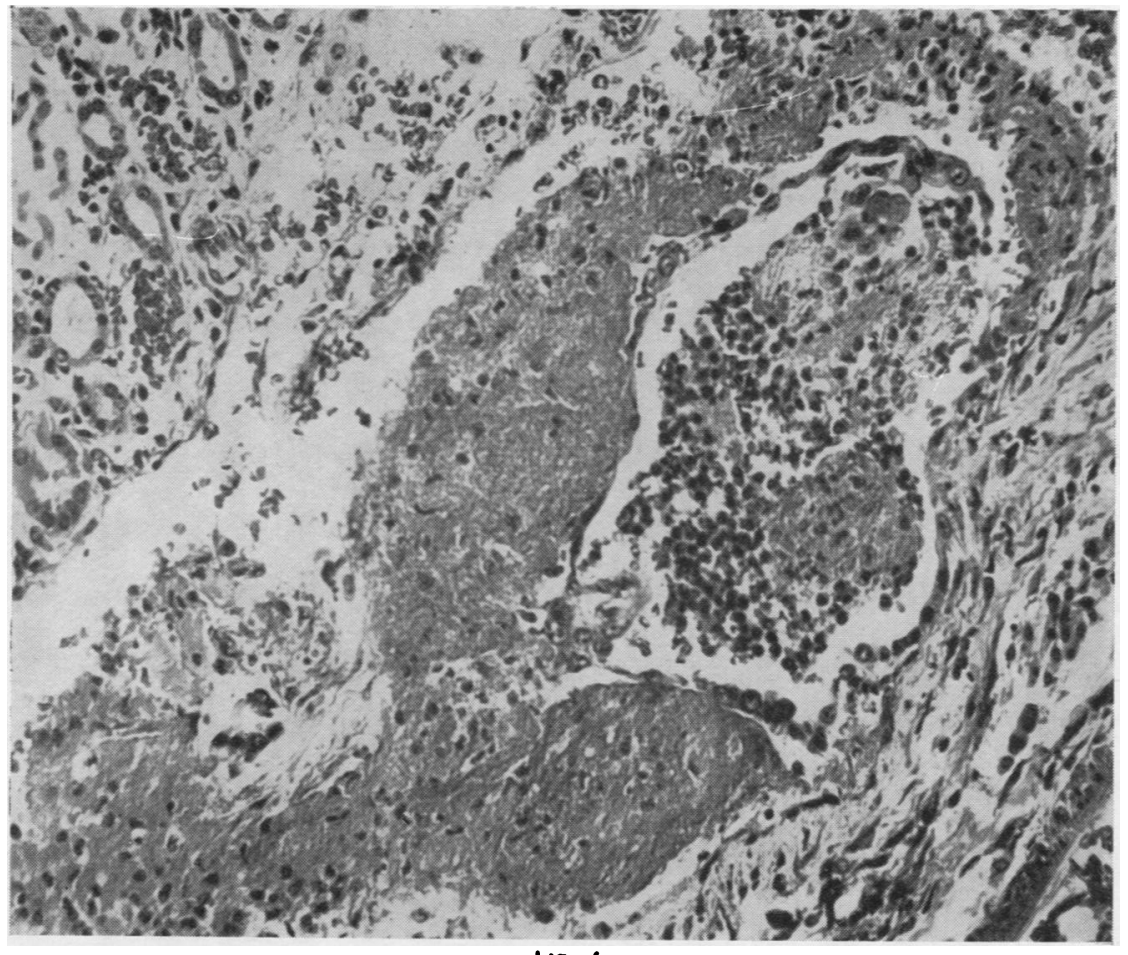

F10. 4

FiG. 4.-Thrombosis of a vein in the boundary zone with early organization of the clot into which has spread thin layer of regenerating tubular epitt.elium. Case 3, haematoxylin and eosin $\times 110$.

Fig. 5.-Focal infiltration of lymphoid and plasma cells in the cortex situated at the distal convoluted tubule, parts of which are necrotic. Case 3, haematoxylin and eosin, $\times 110$

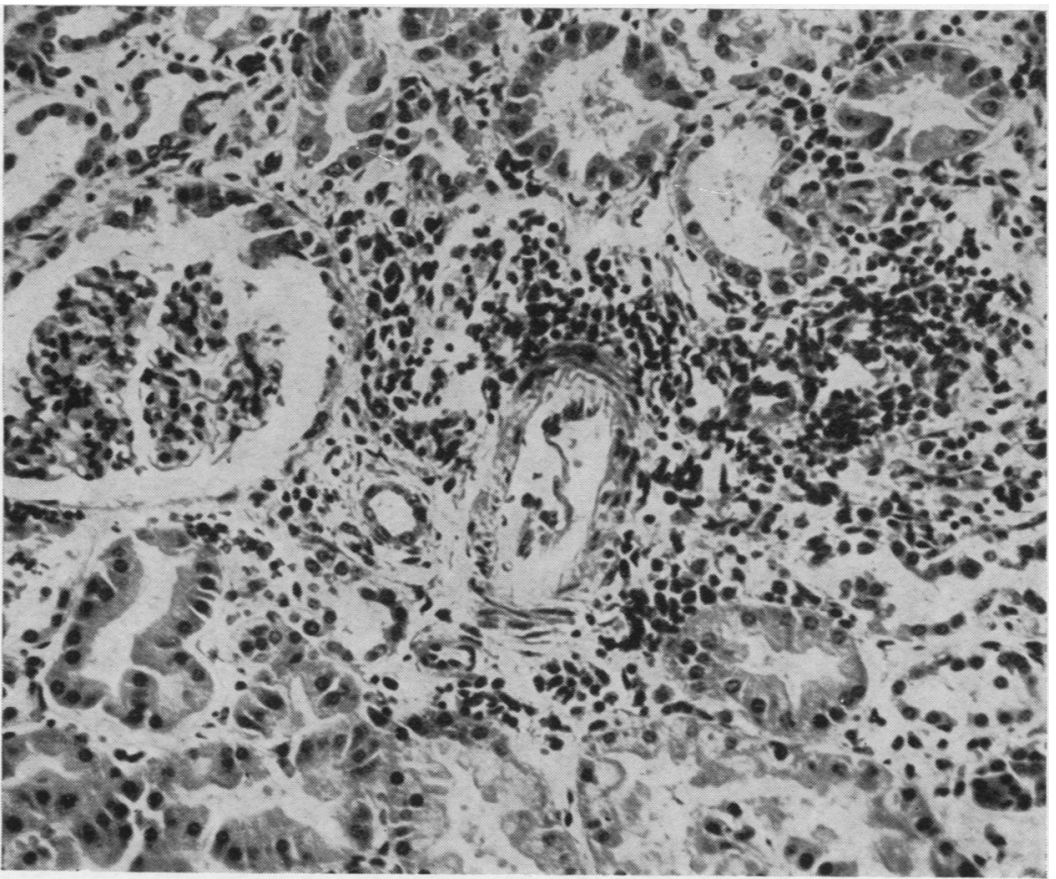

Fio. 5 

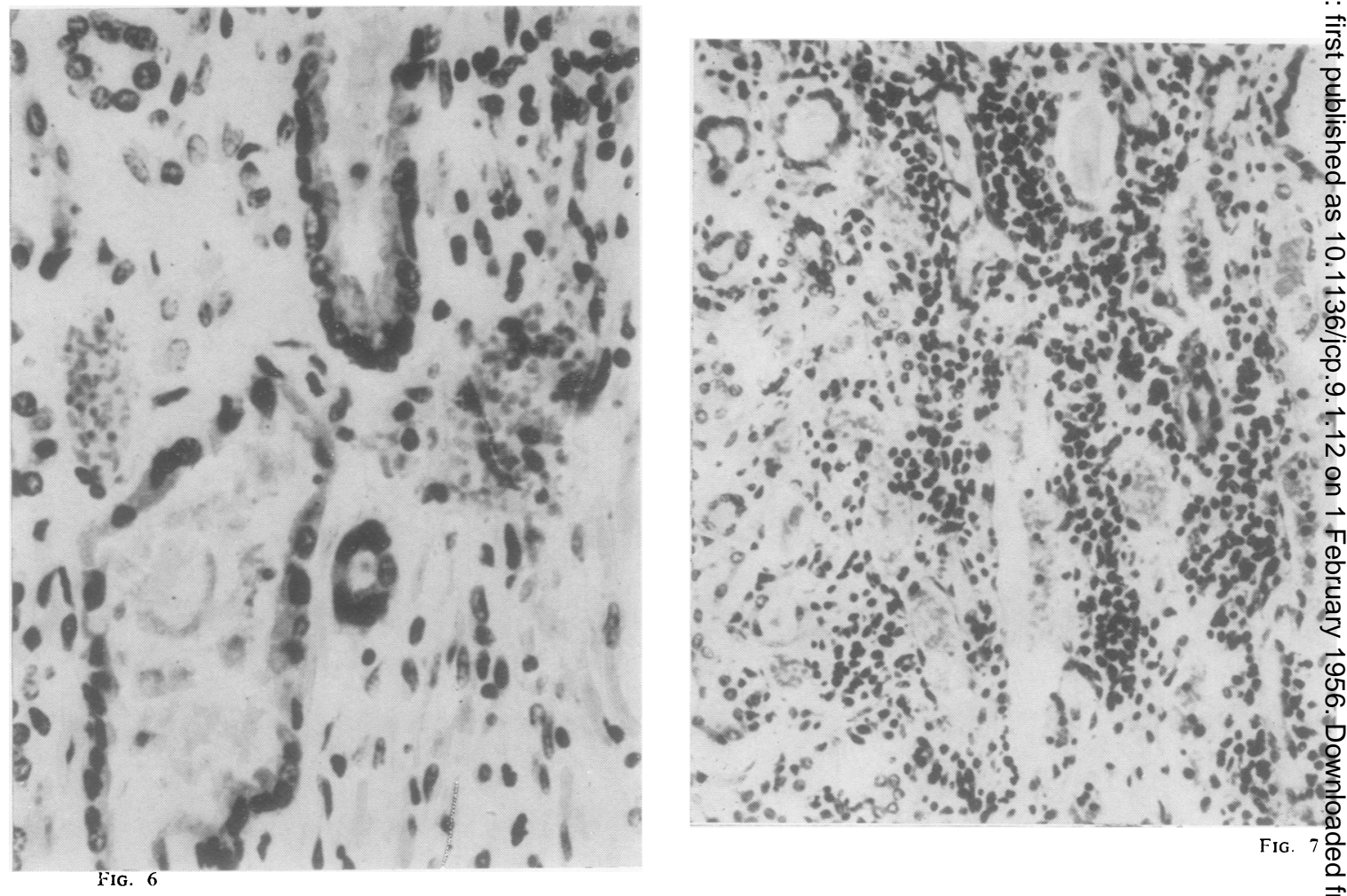

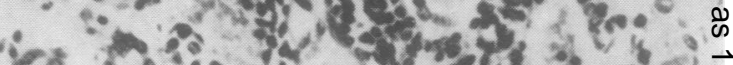
"⿻

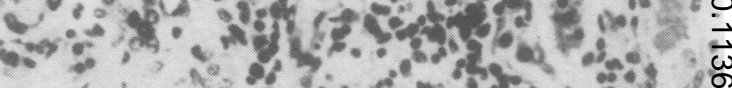

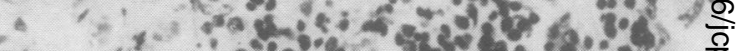

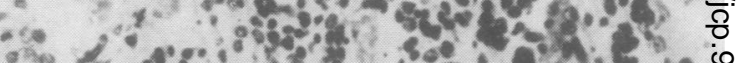

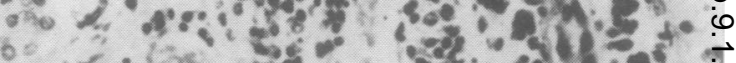

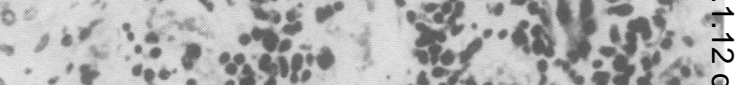

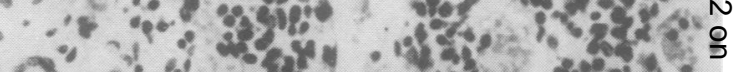

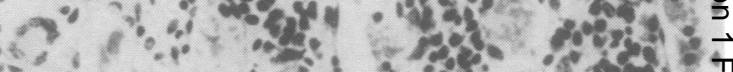

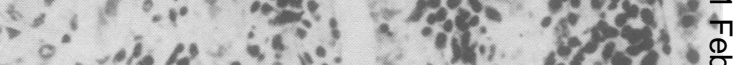

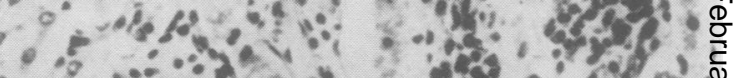

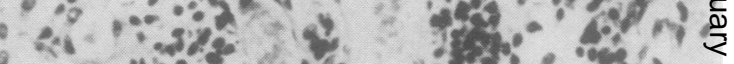
ath

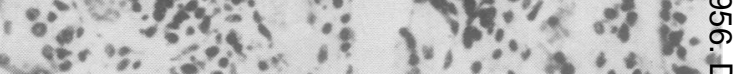

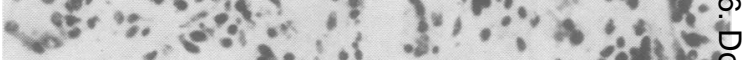
FIG. $7 \frac{2}{\frac{1}{2}}$

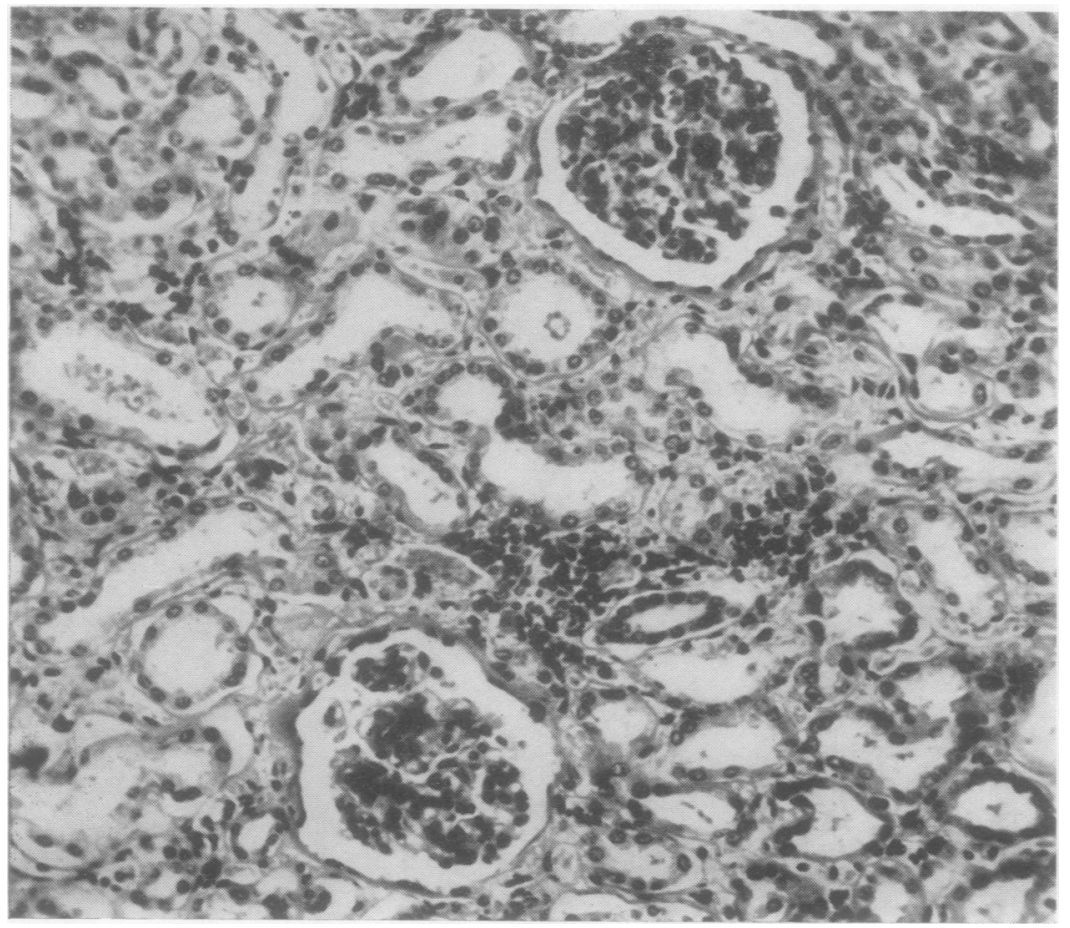

Fig. 6.--Recently regenerated straight tubules in the boundary zone and a loose lymphocytic cellular exudate. Case 8, haematoxylin and eosin, 380 .

Fig. 7.-Heavy peritubular lymphoid infiltration in the boundary zone. Some of the straight tubules contain colloid casts. Case 8, haematoxylin and eosin, 210.

FIG. 8-Focal infiltration of lymphoid cells related to casts extruded by the distal convoluted tubule. Case 8, haematoxylin and eosin, 210 . 
were present, epithelial regeneration was in progress, tubulo-venous anastomoses had occurred, and there was an inflammatory cellular exudate in the interstitial tissue.

In Case 3, surviving 10 days, numerous coarse and finely granular haemoglobin and eosinophilic casts were found mainly in the collecting tubules and ascending limbs of Henle (Fig. 3) ; some colloid and cellular casts were also present. Discrete necroses of straight tubules, particularly in the boundary zone of the cortex and in the pyramid, were in evidence largely at the sites of blockage by casts. Attempts at tubular repair by spreading and regeneration of epithelium was in progress and had produced plicated and bizarre tubular forms. Some of the venules in the boundary zone were thrombosed (Fig. 4), the thrombi were becoming organized, and there was other evidence of tubular rupture and tubulo-venous anastomoses. Collections of lymphocytes, some plasma cells, and a few eosinophil leucocytes were seen around and between many straight and second convoluted tubules, particularly those ruptured or blocked by casts (Fig. 5). The parietal epithelial layer of many Bowman's capsules had become cubical or even low columnar, as if over-vigorous replacement of the previously desquamated epithelium had occurred. Some cloudy swelling was present in the first convoluted tubules, the cortex and medulla were congested, and the latter was oedematous.

A diffuse but not excessively severe form of distal tubular necrosis was found in the kidneys of Case 4, who died on the sixth day. There were moderate numbers of benzidine-positive pigmented casts; focal pyknonecrosis of blocked tubules was present and a cellular infiltration between the straight tubules and near walls of veins was seen. Much of the cortex and many glomeruli were ischaemic, the tubules in the pyramid were separated by oedema and the medulla was congested.

The histological features in Case 5 differed in that haemoglobin casts were not found, and this is of interest, since haemoglobinuria was not reported. This was also found in the case treated at Mount Vernon Hospital. Instead eosinophilic colloid and granular casts were present, tubular regeneration and evidence of recent necrosis was seen, peritubular and perivenous cellular infiltrates were found, particularly in the boundary zone of the cortex and at the second convoluted tubules. There was thrombotic evidence of tubulo-venous rupture.

In the post-traumatic subject (Case 8) who survived 16 days, the Henle tubules and the collecting tubules frequently contained eosinophilic casts some of which were mixed with small groups of red cells. Many Henle tubules were degenerate or focally necrotic and in some irregular tubular regeneration was in progress (Fig. 6). The lymphoid cell infiltration was heavy but irregular in the boundary zone (Fig. 7), and was also present in other parts of the cortex, where it was usually related to extruded casts or ruptured or necrotic second convoluted tubules (Fig. 8). Many glomeruli were distinctly ischaemic. The epithelium of the first convoluted tubules also showed some degenerative changes; their lumina were a little dilated and contained eosinophilic debris. Oedema of the pyramid was evident.

Atypical Cases.-The histological findings in two burned patients differed from the others in that a degenerative change of the first convoluted tubules was associated with evidence of a previous (Case 2) or recent (Case 7) attack of focal distal tubular necrosis.

Case 2.-On admission haemoconcentration was considerable; at first plasma and then blood was transfused. Peripheral circulatory failure developed and in attempting to reverse this a total of 18.6 litres of plasma and blood was transfused in the two and a half days. An acute acholuric haemolytic jaundice (serum bilirubin $10.5 \mathrm{mg} . \%$ ) with considerable haemoglobinuria occurred. The blood urea rose from $80 \mathrm{mg} . \% 12$ hours after burning to $190 \mathrm{mg} . \%$ on the day of death. At necropsy the kidneys were deeply congested, their cut surfaces dripping blood.

No haemoglobin casts were seen and there was no evidence of acute distal tubular necrosis except for a very occasional necrotic focus in a wide Henle loop. However, focal, mainly perivenous, collections of lymphoid cells were found particularly in the boundary zone of the cortex. An occasional Henle tubule appeared recently regenerated and a few colloid casts were found in distal tubules. These findings are evidence of a recently "healed" attack of tubular necrosis unrelated to the burns (see Group 2). The epithelium of the first convoluted tubules was swollen and palestaining and some nuclei had disappeared. Both cortex and medulla were intensely engorged.

It is postulated that the incipient uraemia resulted from an acute accentuation of a previously subclinical tubular dysfunction. The latter had persisted after an attack of distal tubular necrosis which was histologically healed : the accentuation was due to jaundice and acute degeneration of the proximal tubules. Bull et al. (1950) and Oliver (1953) re- 
port that tubular dysfunction may continue for weeks or months after recovery from tubular necrosis.

Case 7.-Uraemia with little or no oliguria in this patient were associated with an active focal necrosis of the distal tubules (see Group 2) and cortico-tubular degeneration. The kidneys together weighed $16 \mathrm{oz}$, were a little swollen, with the cortices pale and broader than usual.

Only a few scattered haemoglobin and colloid casts were present, mostly in collecting and second convoluted tubules. A few foci of tubular necrosis and of epithelial regeneration of the wide Henle tubules were seen : occasional perivenous collections of lymphoid cells and one vein thrombosed by a tubular rupture were additional evidence of a focal tubular attack. Probably of considerable importance was a severe and extensive degeneration of the proximal convoluted tubules in places almost amounting to a necrosis. The pyramids were congested and oedematous.

\section{Group 2}

Details of the 14 patients are given in Table $I$. Unlike the Group 1 patients all but one were children from 2 to 10 years old and the other was a man of 27 years. Each patient was extensively burned; in only two of them was the extent less than $30 \%$ and in the remainder it varied from 45 to $70 \%$ of the body area. The percentage skin areas involved in almost all the patients as well as the mean area burned (which was $52 \%$ ) are similar to those in Group 1. Two patients died within 24 hours of burning and are included because the renal changes may represent the earlier stage of those who survive longer. Four survived four to nine days and the remainder died between 15 and
35 days after burning. Haemoconcentration and fluid intake during the shock phase were, except for Cases 21 and 22, similar to the Group 1 patients.

Urine Flow.-Not one of the patients was oliguric. The daily volumes of urine passed in six representative subjects are given in Table III. Case 9 passed $1,140 \mathrm{ml}$. of urine of S.G. 1020 to 1025 during her 16 hours of survival. Over 1 litre a day was passed by Case 11 except on the last day, when the urinary output fell somewhat. Case 14 , a boy, who was only 4 years old, passed between 350 and $730 \mathrm{ml}$. of urine daily during the first four days. The output may have been less on the fifth day, but even then he passed at least $200 \mathrm{ml}$., but bed-weiting interfered with accurate measurements. The urinary output of Case 15 varied between 500 and $1,000 \mathrm{ml}$. daily. Similarly Cases $10,12,13$, and 16 to 22 passed adequate, normal, or even polyuric volumes of urine on each day. Even in Case 18, a child in whom accurate measurements were spoiled by frequent bedwetting, the volu res which were measured (usually 300 to $600 \mathrm{ml}$. after the fourth day) cannot be considered oliguric for a child of 3 years.

Blood Urea.-Blood or serum urea estimations were carried out on eight subjects (Cases 14 to 16 and 18 to 22 ). The values varied from 26 to $61 \mathrm{mg} . \%$ at the time of death and during the course of the illness. Similar blood urea levels occur in severely burned patients who survive and show no evidence of renal impairment (Bull and England. 1954). Blood urea estimations were not carried out in the other six patients. Two of them (Cases 9 and 10) died at 15 and 16 hours, which was toc soon for significant azotaemia to occur: in a third (Case 17) the ability of the patient to dilute and concentrate his urine makes renal

TABLE III

URINARY OUTPUT AND BLOOD (OR SERUM) UREA LEVELS IN SOME GROUP 2 PATIENTS

\begin{tabular}{|c|c|c|c|c|c|c|c|c|c|c|c|}
\hline \multirow[b]{2}{*}{ Day } & \multirow{2}{*}{$\frac{\text { Case } 11}{\begin{array}{l}\text { Urine } \\
\text { (ml.) }\end{array}}$} & \multicolumn{2}{|c|}{ Case 14} & \multicolumn{2}{|c|}{ Case 16} & \multicolumn{2}{|c|}{ Case 18} & \multicolumn{2}{|c|}{ Case 21} & \multicolumn{2}{|c|}{ Case 22} \\
\hline & & $\begin{array}{l}\text { Urine } \\
\text { (ml.) }\end{array}$ & $\begin{array}{c}\text { Serum } \\
\text { Urea } \\
(\mathrm{mg} . \\
100 \mathrm{ml} .)\end{array}$ & $\begin{array}{l}\text { Urine } \\
(\mathrm{ml} .)\end{array}$ & $\begin{array}{l}\text { Blood } \\
\text { Urea } \\
\text { (mg. } \\
100 \mathrm{ml} .)\end{array}$ & $\begin{array}{l}\text { Urine } \\
(\mathrm{ml} .)\end{array}$ & $\begin{array}{l}\text { Blood } \\
\text { Urea } \\
\text { (mg. } \\
100 \mathrm{ml} .)\end{array}$ & $\begin{array}{l}\text { Urine } \\
\text { (ml.) }\end{array}$ & $\begin{array}{c}\text { Blood } \\
\text { Urea } \\
\text { (mg. } \\
100 \mathrm{ml} .)\end{array}$ & $\begin{array}{l}\text { Urine } \\
\text { (ml.) }\end{array}$ & $\begin{array}{c}\text { Blood } \\
\text { Urea } \\
\text { (mg. } \\
100 \mathrm{ml} \text {.) }\end{array}$ \\
\hline $\begin{array}{r}1 \\
2 \\
3 \\
4 \\
5 \\
6 \\
7 \\
8 \\
10 \\
12 \\
14 \\
16 \\
18 \\
20\end{array}$ & $\begin{array}{l}1.757 \\
1.200 \\
1.100 \\
1.600 \\
1.290 \\
1,340 \\
560\end{array}$ & $\begin{array}{l}350 \\
463 \\
667 \\
730- \\
200- \\
448 \\
360+\end{array}$ & $\begin{array}{l}26 \\
33 \\
46 \\
\\
46 \\
55 \\
36\end{array}$ & $\begin{array}{r}487 \\
832 \\
340 \\
1.150 \\
1,870 \\
1,035 \\
1,285 \\
1,075 \\
1.070 \\
680 \\
620\end{array}$ & $\begin{array}{l}55 \\
40\end{array}$ & $\begin{array}{l}1,254 \\
980 \ldots \\
80 \ldots \\
665 \ldots \\
296 \ldots \\
570 \ldots \\
300 \ldots \\
295 \ldots \\
360 \ldots \\
328 \ldots \\
535+ \\
540+ \\
400 \ldots \\
260 \ldots\end{array}$ & 37 & $\begin{array}{r}1.080 \\
530 \\
1.585 \\
1.150 \\
730 \\
690 \\
1,180 \\
1,680 \\
1,650 \\
1,150 \\
660 \\
875\end{array}$ & $\begin{array}{l}46 \\
50 \\
53 \\
53 \\
41 \\
44 \\
39 \\
\\
40 \\
54 \\
58\end{array}$ & $\begin{array}{r}1,135 \\
1,036 \\
1,050 \\
374\end{array}$ & 58 \\
\hline
\end{tabular}

All patients except Case 11 were children. 
impairment unlikely (vide infra), but in Cases 11 to 13 this possibility cannot reasonably be eliminated.

Haemoglobinuria. - Haemoglobinuria was known to occur in only four of the 14 patients (Table I). In Case 9 it was noted a few hours after burning when the urine was pale red, but a few hours later it was normal in colour. In Case 15 , however, there was no evidence of haemoglobinuria until the third day, when it occurred in association with a true haematuria. Whether it was a true haemoglobinuria or not is difficult to estimate. Next day the supernatant urine after centrifugalization was free of haemoglobin, whilst a deposit of red cells was still present. Necropsy revealed that the haematuria was the result of a ruptured calyceal vein. A heavy and true haemoglobinuria occurred in Cases 21 and 22. It started early in both children, was intermittent for two days in the former, but in the latter was prominent for two or three days.

Clinical Uraemia.-This was not suspected during the course of the patients' illnesses.

Causes of Death.-Significant clinical and necropsy findings are included in Table I. Acute respiratory distress developed in Cases 9 and 10 . At necropsy atelectasis was found in both patients and was associated with pulmonary oedema in the former. In seven patients severe infective complications, usually septicaemia or bronchopneumonia, were found, and in one of them (Case 17) agranulocytosis due to sulphonamide intoxication was also present. Case 12 died suddenly, and at necropsy acute coning of the medulla oblongata was seen. A pulmonary infarct was found in Case 16 ; diarrhoea from aureomycin therapy helped to exhaust Case 19, and bleeding from an acute duodenal ulcer (Curling's ulcer) may well have played a part in the death of Case 20. No significant infective or other complications were to be found in Case 22.

Thus the causes of death as revealed by clinical observation and necropsy findings generally appeared to be unrelated to uraemia.

Renal Function.-In the six patients studied there was no significant reduction in the urea clearance values (Table IV), which varied from time to time in some patients. Values from $30 \%$ to $85 \%$ of normal were found in Case 14: similar variations from $45 \%$ to $120 \%$ and $80 \%$ to $100 \%$ of normal were also observed in Cases 16 and 20 , but successive values of $40 \%$ and $41 \%$ of normal were found in Case 21 on the two days before she died. The concentrating power of the kidneys as reflected in the specific gravity or osmolarity of the urine was moderately good, and in two patients (Cases 16 and 17) evidence of adequate diluting power was also obtained (S.G. 1004 and 239 m.osmols per litre respectively). The concentration of the urine often varied from day to day. Case 16, for example, passed a dilute urine on the second day, but two days later the urine was moderately concentrated $(888 \mathrm{~m}$.osmols per litre), and thereafter the daily concentration varied from 243 to 821 m.osmols per litre. Similarly the milli-osmolarity in Case 21 varied from 344 to 876 throughout her illness. No patient, however, secreted a highly concentrated urine. This may have been the result of an adequate water intake and urinary output. On the other hand, it may have been the result of a subclinical lowering of the tubular reserves similar to that postulated in Case 2, a man in whom there was evidence of a recently "healed" focal distal tubular necrosis. Acute renal failure in him may have been partly the result of an impaired tubular power before he was burned.

\section{The Kidneys in Group 2 Patients}

Thirteen subjects had either a focal necrosis of the distal tubules at different morphological stages of activity or the healing or healed evidence of a recent focal attack. In one patient (Case 22) the histology was atypical.

Early Focal Distal Tubular Necrosis.-Cases 9 and 10 , surviving only 15 and 16 hours, are included in the series because they probably represent the earlier stage of the later phenomenon. The kidneys were dark with congestion, particularly the pyramids, and the capsules were tense.

Histology.-Only a few scattered haemoglobin casts-amorphous and granular forms-were present, mainly in the collecting tubules (Fig. 9) and in a few ascending and spiral portions of the distal tubules. Early discrete tubular necroses (pyknosis) were restricted to some of the tubules blocked by casts.

Later Focal Distal Tubular Necrosis.-Three patients (Cases 11 to 13) who died eight and a half, six, and 35 days after burning had a focal distal tubular necrosis in a later histological phase. In Case 13 a few distal convoluted and straight Henle tubules were locally distended by colloid or less commonly granular casts (Figs. 10 and 11). No haemoglobin casts were seen. The epithelium of the distended parts was usually thin, the nuclei were hyperchromatic, and very occasional mitoses were found (Fig. 10). In other words tubular regeneration of formerly necrotic parts of the 
tubules was in progress. Focal sollections, mainly of lymphoid cells but also containing fibroblasts, were found around some of these tubules (Fig. 11) and around the walls of veins in the boundary zone of the cortex. An occasional venule was thrombosed and organization of the thrombus was taking place. The proximal convoluted tubules were a little distended and some albuminous degeneration was present. The histological features in Cases 11 and 12 were similar, but a few haemoglobin casts were seen (Fig. 9), and there were occasional tubulo-venous thrombi in the boundary zone (Fig. 12). Localized necrosis of a few Henle tubules, including some which did not contain casts, was also seen, but visible necrosis is to be expected, since these patients died sooner than did Case 13. Tubular regeneration was also in progress (Fig. 13).

"Healing" and "Healed" Focal Distal Tubular Necrosis.-The morphological changes in the kidneys of eight patients (Cases 14 to 21) are believed to represent the healing or healed residue of a recent focal distal tubular necrosis. Focal collections, mainly of lymphoid cells, were present in the kidneys of each patient; they were often perivenous and were commonly located in the boundary zone of the cortex (Fig. 14) or related to second convoluted tubules. In three patients (Cases 14, 15, and 21) occasional organizing venous thrombi in this part of the kidney indicated former tubulo-venous rupture (Fig. 15). Direct evidence of tubular necrosis was slight or absent and was seen only in two or possibly three patients. In three cases casts were seen in a few distal tubules ; they were granular and eosinophilic in Case 14, pigmented in Case 20, and of both kinds in Case 21. In the kidneys of four subjects (Cases 14, 18, 19, and 21) parts of an occasional straight Henle tubule showed evidence of recent regeneration.

The term "healing" is applied when tubular evidence of necrosis or regeneration still persists (Cases 14, 18, 19, and 21). Case 14, dying at seven days after burning, showed more tubular evidence of a recent focal attack than the others.

The term "healed" is used when there is no tubular evidence of focal tubular necrosis (Cases $15,16,17$, and 20 ). The characteristically located lymphoid cell collections and in one patient (Case 15) an organizing venous thrombus (Fig. 15) were accepted as the residue of a focal distal tubular necrosis. Taken as a group, this appears to be a reasonable deduction even though direct evidence of tubular damage was not detectable. The duration of survival, 15 to 21 days, was probably consistent with histologically effective tubular repair.
Atypical Case and Prevention of Oligaemia.- $\vec{\Rightarrow}$ Case 22 differed from the others in Group 2 in $\stackrel{5}{9}$ that multiple haemoglobin casts were seen histo- $\frac{}{C}$ logically. The urinary output of this child (Table 흠 III) was almost polyuric for three days and the $\frac{\bar{\sigma}}{\vec{\sigma}}$ urine was dilute. Haemoglobinuria appeared $\stackrel{\Phi}{\varrho}$ early, was prominent, and continued for two days or longer. Renal function was adequate or nor- $\vec{\circ}$ mal and significant azotaemia did not occur (Table IV). A special feature in this child and in Case $21 \overrightarrow{\vec{\omega}}$ was that, after the initial haemoconcentration had $\stackrel{\circ}{\stackrel{\circ}{\circ}}$ been corrected, the plasma and red cell volumes $\overline{0}$ were maintained more or less within normal limits 6 by energetic transfusions guided by repeated blood volume estimations. Indeed, during the first three $\vec{N}$ days 10.8 litres of plasma plus 1 litre of blood was 은 given to Case 21 in addition to 4 litres orally, and 6.4 litres of plasma plus 1 litre of blood to Case $\frac{\mathbb{D}}{\mathcal{D}}$ 22. The special biochemical feature was a very $\frac{0}{\mathrm{C}}$ low serum potassium $(11 \mathrm{mg}$ \% ) on the day she died.

Histology.-There were many haemoglobin $\vec{\oplus}$ casts in the collecting tubules and numbers in the ascending and convoluted parts of the distal tubules. Only some appeared blocked by casts, and occasional pyknonecrotic epithelial foci were seen, but they were not numerous. Small perivenous and peritubular lymphoid cell collections $\stackrel{\varnothing}{\varnothing}$ were present, but they were infrequent. There was $\overrightarrow{\vec{B}}$ an eosinophilic and granular cytoplasmic degener- $\frac{3}{3}$ ation of the neck-like beginning of the first convoluted tubules the remainder of which was pale and swollen. The lumina were obliterated, but the second convoluted tubules were moderately dilated.

The unusual combination was many haemoglobin casts and few necroses in the distal and collecting tubules, that is a diffuse cast state with focal tubular necrosis. The scarcity of necrotic epithelium both in this child and in Case 21 may have been due to the absence of oligaemia and $\frac{D}{2}$ renal ischaemia resulting from massive transfusion, even though haemoglobinuria was con- N siderable in both patients (vide infra). The histo- $N$ logically numerous pigmented casts in Case 22 요 were the result of the prolonged haemoglobinuria : had she survived longer, they might have been progressively removed by the unobstructed urinary flow through the tubules, and the histological picture would then have resembled that observed + in other cases of focal distal tubular necrosis such as Case 21.

\section{Discussion}

In burned subjects distal tubular necrosis may $\stackrel{\mathbb{D}}{\circ}$ be associated with one of three clinico-biochemical syndromes. First, severe oliguria or anuria cul- 8 


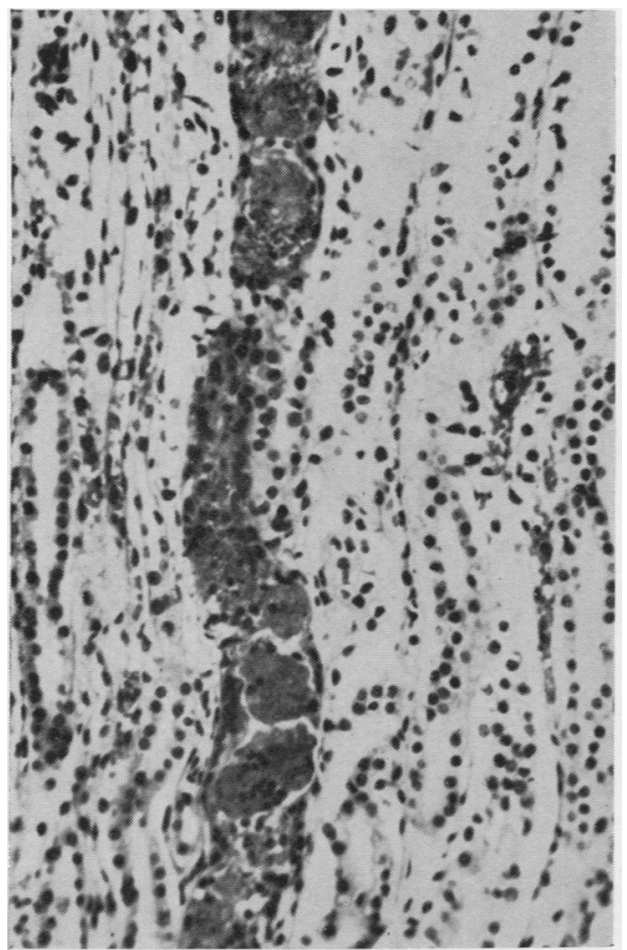

FIG. 9

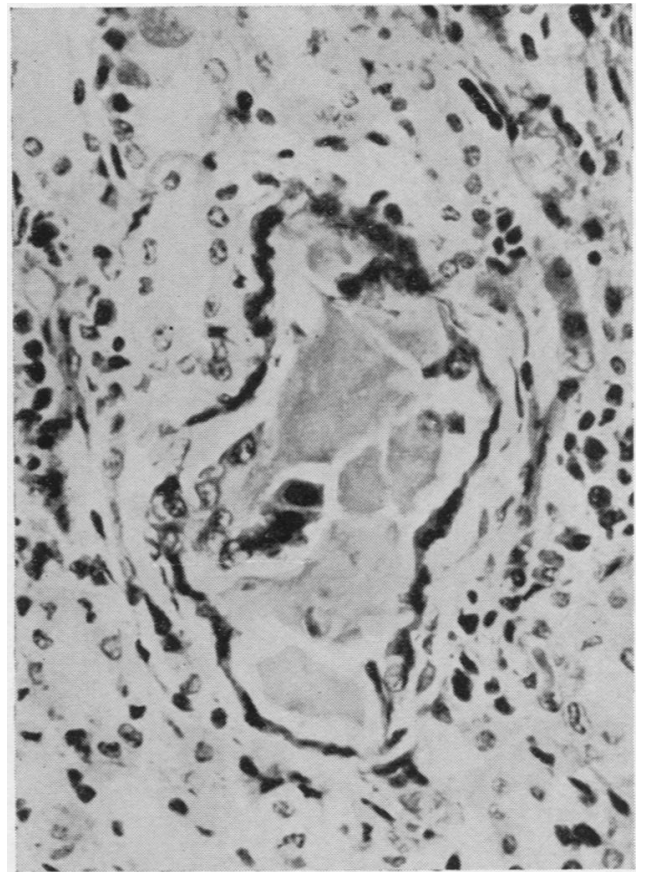

FIG. 10
FIGS. 9 to 15.-Focal distal tubular necrosis.

Fig. 9.-An occasional Henle tubule is distended by a haemoglobin cast. The epithelium of this tubule is irregularly necrotic. Case 9, haematoxylin and eosin, $\times 210$.

Fig. 10.-An occasional straight tubule in the deep half of the cortex is focally distended by a colloid cast and the epithelium is thin and hyperchromatic as if in the process of regeneration. Case 13, haematoxylin and eosin, $\times 380$.

Fig. 11.-One of the few focal collections of lymphoid cells which lie near ruptured Henle tubules some of which show irregular epithelial regeneration. The remains of casts in these formerly necrotic tubules are still visible. Case 13, haematoxylin and eosin, $\times 380$.

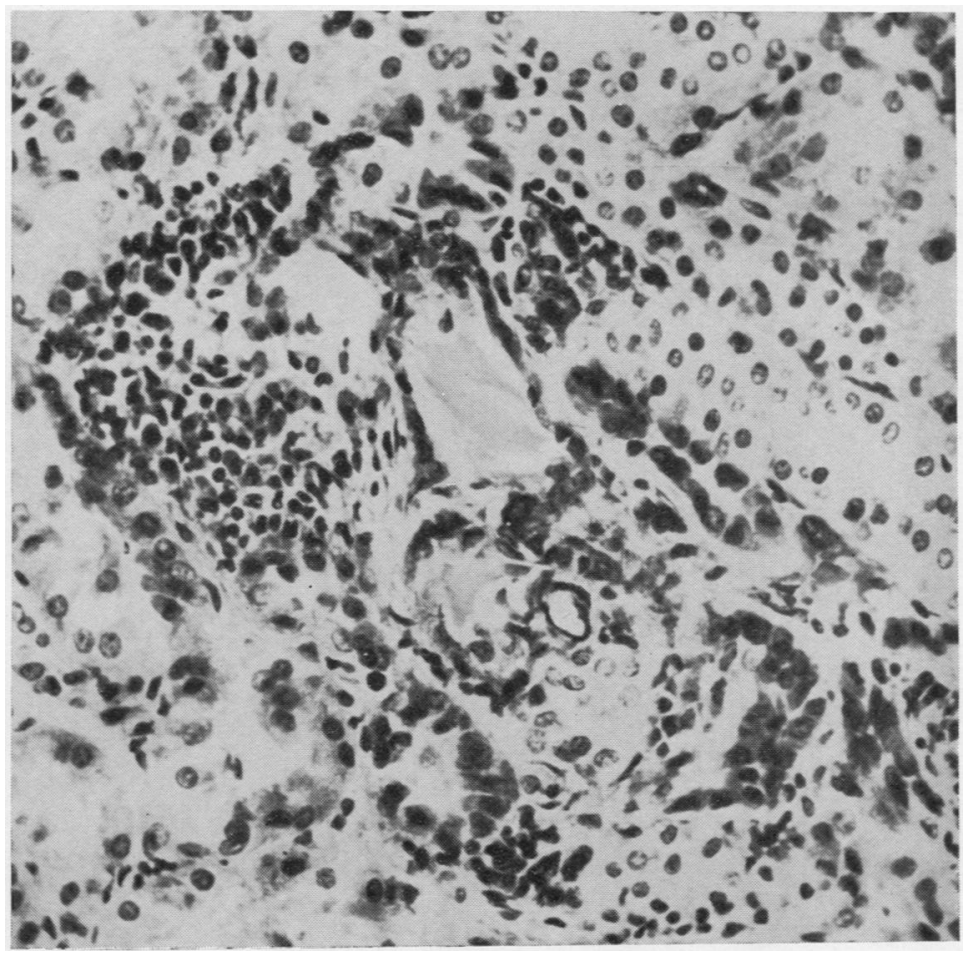




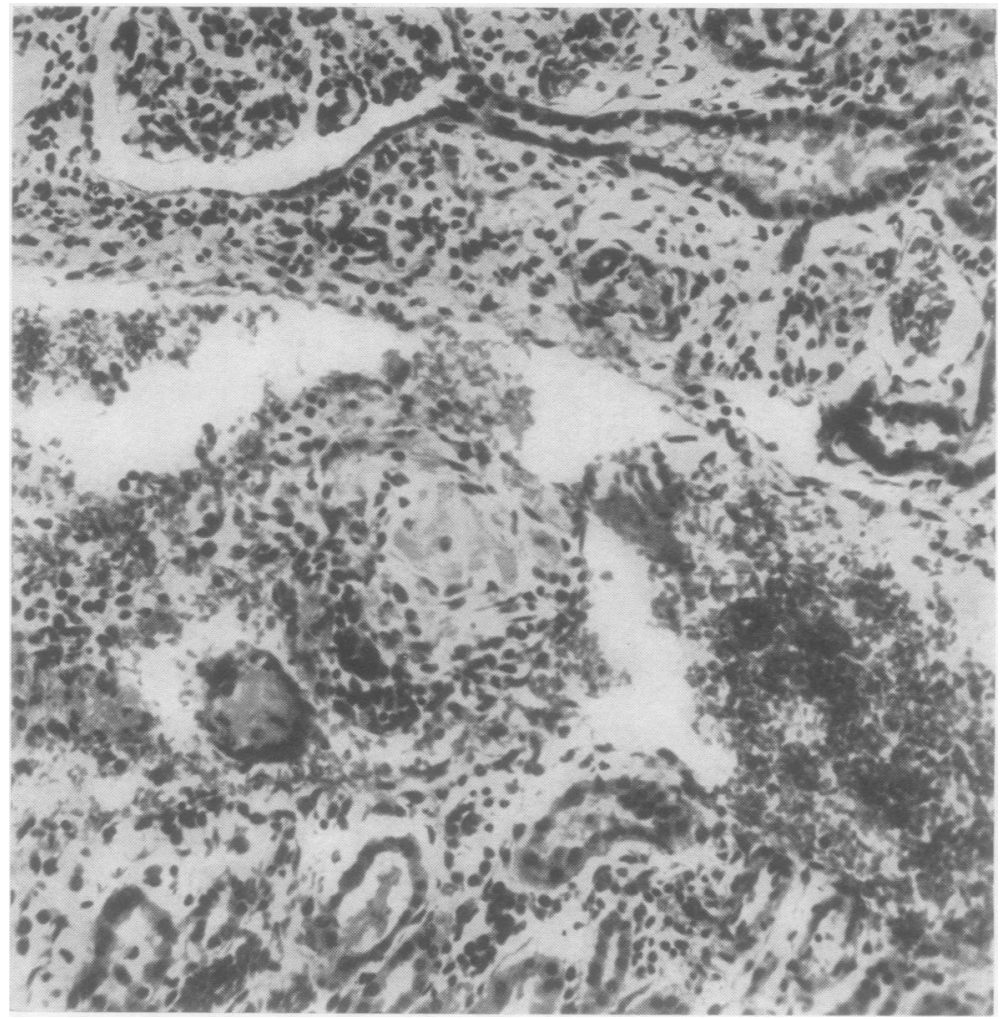

FIG. 12

Fig. 13

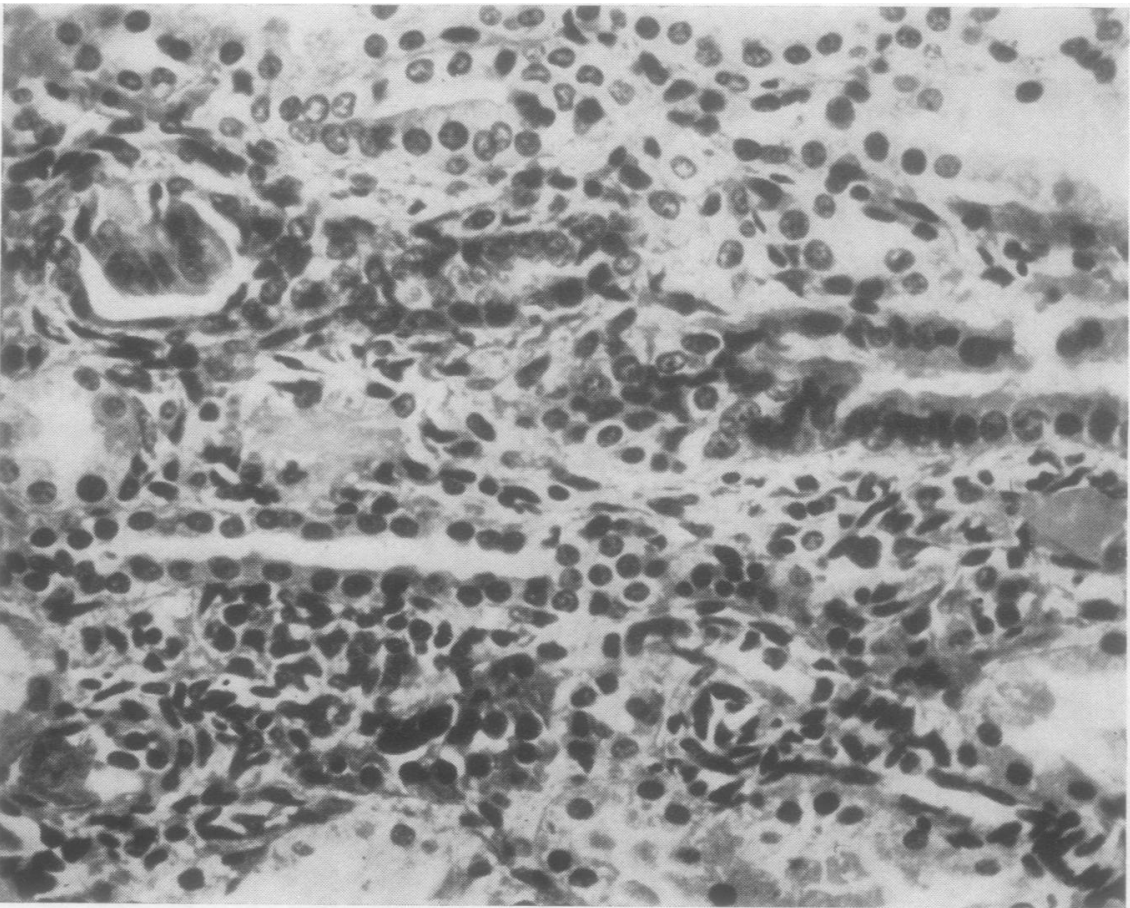


FIG. 12.-An occasional vein in the boundary zone is thrombosed. The clot is beginning to organize and irregular migration of tubular epithelium indicates former tubulovenous anastomosis. Case 12, haematoxylin and eosin, $\times 210$.

FIG. 13.-Regeneration of a few focally necrotic tubules is in progress and has produced bizarre tubular forms. Parts of two tubules contain colloid casts. To the left of the centre there is an intertubular infiltration of lymphoid cells. Case 12, haematoxylin and eosin, $\times 380$.

Fig. 14.-A few focal pe:ivenous collections of lymphoid cells in the boundary zone are part of the residue of a recent attack of focal D.T.N. Case 18, haematoxylin and eosin, $\times 210$.

FIG. 15.-An occasional organizing thrombus in a boundary zone vein is part of the residue of a recent attack of focal D.T.N. Case 15 , haematoxylin and eosin, 210.

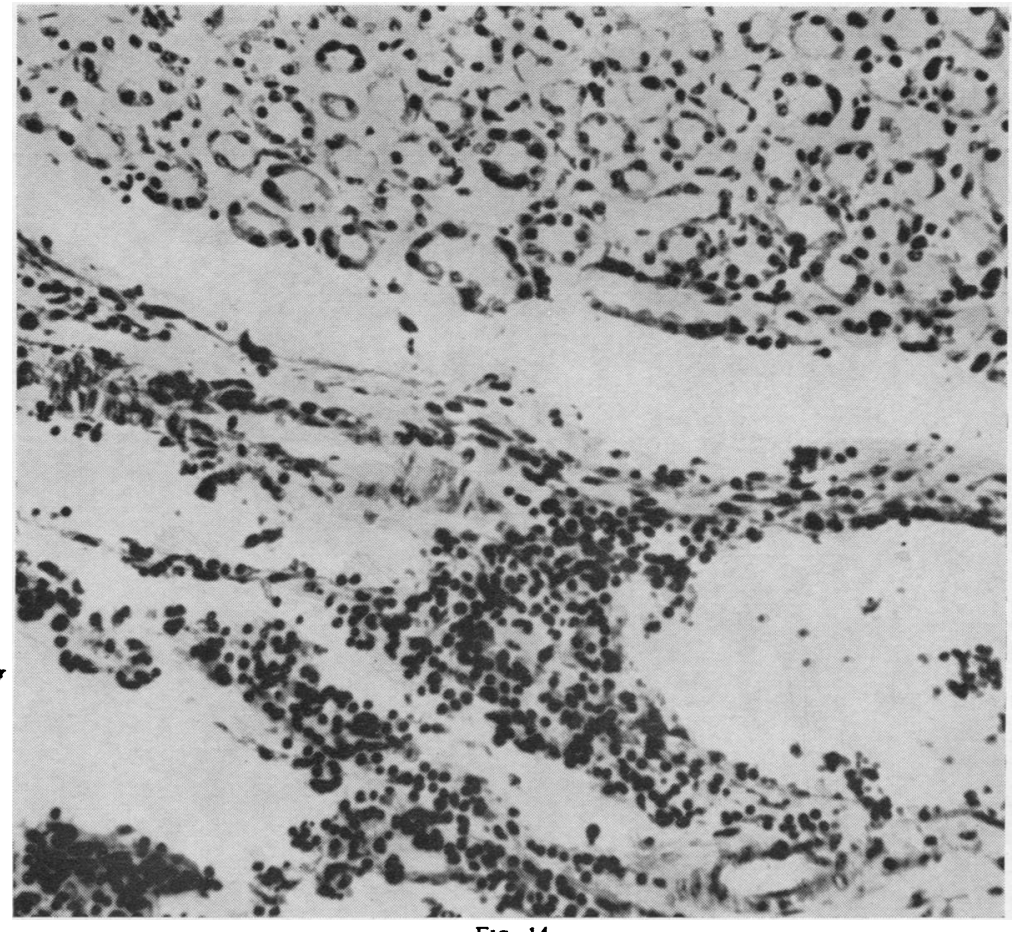

FIG. 14

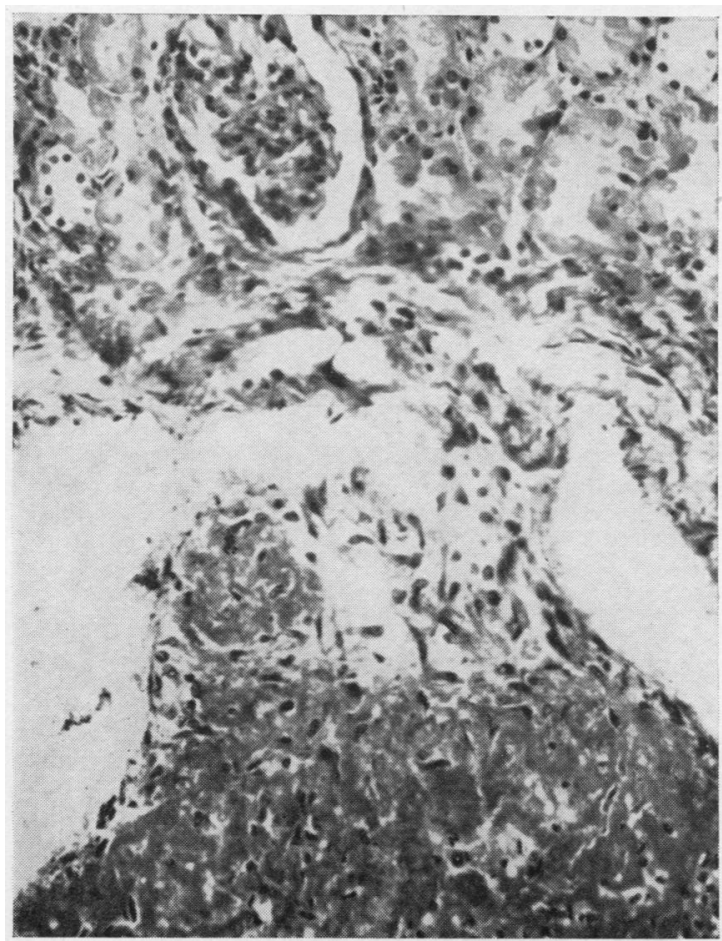

Fig. 15 minating in uraemia may develop ; second, uraemia may occur without significant reduction in the flow of urine (Group 1) ; and third, neither oliguria nor uraemia may be found (Group 2). All the patients were extensively burned and the mean skin areas involved were $66 \%, 58 \%$, and $52 \%$ of the body area in the respective groups. Certainly the difference between the areas burned in Group 1 and Group 2 patients is not significant. All but one of the Group 1 patients were adults or adolescents, whilst all but one of the Group 2 patients were children.

In five of the seven Group 1 burned patients a diffuse distal tubular necrosis was found and in another a focal distal tubular necrosis was associated with a severe and extensive cortico-tubular degeneration. Twelve other burned subjects with distal tubular necrosis (unpublished data) died with severe oliguria or anuria, four of whom lived long enough to develop uraemia. Ten of them had a diffuse distal tubular necrosis and in the other two the change was focal. In both the oliguric and non-oliguric groups, the diffuse change was characterized by the early appearance of haemoglobin casts in many collecting and wide Henle tubules and in distal convoluted tubules. This differs from Dible's latest account (Bull and 
Dible, 1953) of distal tubular necrosis (" acute tubular necrosis" in their terminology), since he reports that pigmented casts do not appear in numbers until about the second or third day of oliguria. However, Dible's series of 62 cases included only two kidneys from burned patients and the absence of significant haemoglobinuria in these may have been responsible for his experience. In both groups, frequently the tubules were blocked by casts and this was often associated with discrete necrosis of the epithelium. Necrosis occurred less frequently in tubules which did not contain casts. In both groups rupture of tubules, dislocation of casts, tubular regeneration, peritubular and perivenous infiltration by lymphoid and other inflammatory cells, tubulo-venous anastomoses and thrombi were found in patients who survived sufficiently long. Histological examination by the writer cannot distinguish between oliguric and non-oliguric forms of diffuse distal tubular necrosis. The difference probably has a functional rather than a morphological basis and may depend on differences in renal blood flow or glomerular filtration which clearly would be difficult if not impossible to distinguish histologically.

Other workers have referred to the absence of significant oliguria in some fatally burned patients, the kidneys of whom showed the changes now referred to as distal tubular necrosis. Goodpastor, Levenson, Tagnon, Lund, and Taylor (1946) mention four patients who had only a transient and limited oliguria in the shock phase and in whom pigmented casts, tubular necrosis, and regeneration were found histologically. In these patients "there was evidence of impaired ability to clear non-protein nitrogen in the face of a urine output of a litre or more daily." Four patients of Shen. Ham, and Fleming (1943) may also belong to this category. Homer Smith (1951) refers to two severely injured patients studied by Burnett and his colleagues at the Italian front who may also be included, and more recently Teschan, Post, Smith, Abernathy, Davis, Gray, Howard, Johnson, Klopp, Mundy, O'Meara, and Rush (1955) described cases of post-traumatic uraemia without oliguria occurring after battle wounds.

Renal Function in Uraemic Subjects.-Biochemical examination of the blood and urine threw some light on the functional renal disturbance of four uraemic subjects (Table IV). On the one hand, an adequate or normal flow of urine and considerable azotaemia were associated with low urea clearance values and a poorly concentrated urine. These findings suggest that, although the glomerular filtration rate was somewhat lowered,

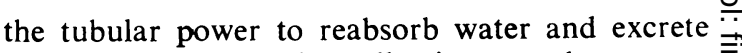
urea were reduced, thus allowing an adequate or normal volume of urine to be secreted and azotaemia to develop. However, the urea clearance 흠 test is dependent both on glomerular filtration $\frac{\bar{m}}{\frac{5}{\sigma}}$ and on tubular function, so that it is not possible $\mathbb{\mathbb { Q }}$ on the available data to distinguish reduction of filtration clearly from tubular dysfunction. Further investigation by endogenous creatinine or inulin $\vec{\circ}$ clearance techniques is required.

On the other hand, two of the three patients investigated had considerable tubular power to reabsorb sodium and chloride as revealed by the 0 low concentrations and small daily output of these ions in the urine, and in the third patient the re- $\vec{N}$ absorptive power was moderately good. The low 을 urinary values were not due to salt deprivation or $\rightarrow$ associated with low serum values; indeed, the $\mathbb{\Phi}^{7}$ serum chloride and sodium levels were normal or 을 raised. In this persistence of reabsorptive power for sodium and chloride, the non-oliguric but uraemic patients differ from the oliguric-uraemic $\overrightarrow{0}$ subjects studied by Bull and his co-workers (1950). \% They found a considerable concentration of $\square$ sodium and chloride in the urine associated with falling or low serum levels of these ions during both the oliguric and early diuretic phases. In their patients tubular power to reabsorb sodium $\frac{\circ}{\Phi}$ and chloride was virtually absent. Therefore $\stackrel{\varrho}{\vec{O}}$ renal function in the present subjects is different from that found by Bull in patients during the eariy diuretic phase of the anuric type of acute? renal failure, even though both groups of patients were uraemic and urine flow was adequate or용 normal.

Urinary retention of sodium and chloride commonly occurs for a few days in burned patientso who show no evidence of renal failure (Bull and England, 1954). It is probably a physiologicalo phenomenon, extrarenal in origin, and probably $\vec{D}$ related to the hyperactivity of the adrenal cortex which occurs after burning (Sevitt, 1951, 1954. N 1955).

Azotaemia.- It may be argued that the azotaemia found in the Group 1 patients is largely due $\omega$ to an increased protein katabolism as a result of which large quantities of urea and other nitro-e genous end-products are formed. It is true that $\$$ extensively burned patients and animals are in $a^{+}$ state of negative nitrogen balance and that in- $\frac{0}{0}$ creased quantities of urea, creatinine, and other $\frac{\vec{O}}{\mathbb{D}}$ nitrogenous compounds are excreted in the urine $\stackrel{?}{\odot}$ (Taylor, Levenson, Davidson, Adams, and Mac- $\stackrel{\mathbb{Q}}{\varrho}$ Donald, 1943 ; Clark, Peters, and Rossiter, 1945)우 However, the blood urea levels in the Group 20 
patients were considerably lower than in the Group 1 patients, yet the patients in both groups had extensive burns of similar percentage area. Blood urea values similar to those in Group 2, and usually between 40 and $60 \mathrm{mg}$. \%, are also found in severely burned patients who survive and show no evidence of renal impairment (Bull and England, 1954 ; personal experience). In only a minority of patients does the blood urea rise to $200 \mathrm{mg}$. per $100 \mathrm{ml}$. or more. Some of these patients have considerable oliguria, but in others (Group 1) oliguria is slight, transient, or absent. Both the oliguric and non-oliguric patients have other evidence of uraemia, such as acidaemia, hyperpotassaemia, hiccups, polypnoea, drowsiness, etc. Indeed, terminal glycosuria consistent with severe tubular dysfunction occurred in two patients, in one of whom the blood glucose level was determined and found to be normal.

If quantitative differences in endogenous or exogenous protein katabolism are responsible for the respective high and only slightly raised blood urea levels in Group 1 and 2 patients, then the feeding of an excessively high-protein diet to an extensively burned subject should produce a significant azotaemia.

By fortuitous circumstances a severely burned child 2 years old was placed on a very high protein intake of about $84 \mathrm{~g}$. protein per day. Two weeks later the blood urea was only $28 \mathrm{mg}$. \%. The high protein intake produced a large total excretion of urea and a large urinary volume $(600$ $\mathrm{ml}$. on the day of the test).

All the available evidence supports the belief that severe azotaemia is due primarily to renal impairment, although no doubt excessive nitrogen katabolism (and high protein feeding) accentuate the condition when the kidneys are damaged.

Focal Distal Tubular Necrosis.-Qualitatively the earlier histological phases of the focal condition differed in no way from the diffuse form of distal tubular necrosis. The difference was quantitative, casts were few, necroses were not numerous: few tubules were involved. The involvement of few nephrons was the essential histological difference from the diffuse form of the condition, and in general was the morphological basis between non-uraemic and uraemic forms of distal tubular necrosis.

The diagnosis of the "healing" or "healed" phase of focal distal tubular necrosis in eight patients was made largely by the finding of characteristically situated cellular foci around venules or between tubules in the boundary zone or at second convoluted tubules. This was associated with thrombotic evidence of tubulo-venous rupture in three subjects and in four patients there was a little tubular necrosis or recent regeneration.

The residual interstitial cellular collections might have led to the diagnosis of interstitial nephritis if the entire histological process was not borne in mind. It is therefore possible that some cases of so-called interstitial nephritis are in reality the healed or healing residue of distal tubular necrosis.

Pathogenesis.-Two inter-related factors, haemoglobinuria and oligaemia, will be considered.

Haemoglobinuria.-Intravascular haemolysis is a common and early accompaniment of extensive burns. If the concentration of free haemoglobin in the plasma surpasses a threshold level haemoglobinuria results. This may be continuous or intermittent during the first day or two, but occasionally may last longer. It may also be slight or transient and as a consequence easily overlooked. When the urine is deeply red or reddishbrown haemoglobinuria will be easily recognized. Thus the recording of clinically observed haemoglobinuria is an index of its severity and the incidence of this clinically known haemoglobinuria will reflect the frequency of severe haemoglobinuria.

Haemoglobinuria has been associated with impairment of renal function in burned subjects by Shen, Ham, and Fleming (1943) and Goodpastor et al. (1946). Five out of seven Group 1

TABLE V

FREQUENCY OF HAEMOGLOBINURIA AFTER BURNING IN PATIENTS WITH DISTAL TUBULAR NECROSIS (D.T.N.) COMPARED WITH INCIDENCE IN FATALLY BURNED PATIENTS WITHOUT TUBULAR NECROSIS

\begin{tabular}{|c|c|c|c|}
\hline \multicolumn{2}{|c|}{ Classification of Patients } & \multirow{2}{*}{$\begin{array}{l}\text { No. of } \\
\text { Patients }\end{array}$} & \multirow{2}{*}{$\begin{array}{l}\text { No. with Known } \\
\text { Haemoglobinuria } \\
\text { (\% of Group) }\end{array}$} \\
\hline Histology & Clinical Pathology & & \\
\hline D.T.N. & $\begin{array}{l}\text { Severe oliguria (or anuria) } \\
\text { with uraemia if survival } \\
\text { longer than } 4 \text { days }\end{array}$ & 12 & $10(83 \%)$ \\
\hline $\begin{array}{l}\text { D.T.N. } \\
\text { D.T.N. }\end{array}$ & $\begin{array}{l}\text { Uraemia but no oliguria } \\
\text { No oliguria. No uraemia }\end{array}$ & $\begin{array}{r}6 \\
14\end{array}$ & $\begin{array}{l}4(66 \%) \\
4(28 \%)\end{array}$ \\
\hline $\begin{array}{c}C o \\
\text { No renal } \\
\text { tubular } \\
\text { necrosis }\end{array}$ & $\begin{array}{l}\text { ntrol Group } \\
\text { No oliguria. No uraemia }\end{array}$ & 24 & $3(12 \%)$ \\
\hline
\end{tabular}

burned patients were known to have haemoglobinuria, but if Case 2, which was histologically atypical, is eliminated the analysis may be assessed as in Table V. Here is listed the incidence of known haemoglobinuria in four groups of fatally burned patients. Three groups had the histological features of distal tubular necrosis and the fourth was a control group of non-oliguric nonuraemic patients without renal tubular necrosis. 
Ten of the 12 patients ( $83 \%$ ) who became severely oliguric were known to have haemoglobinuria, so too were four of the six $(66 \%)$ Group 1 subjects, but in only four of the $14(28 \%)$ Group 2 patients was this condition recorded. The incidence was only three in the 24 patients $(12 \%)$ of the control group. In other words, haemoglobinuria deep enough to be readily recognized was generally found in patients who developed renal failure whether or not oliguria occurred. It was uncommon in those without renal failure whether or not focal distal tubular necrosis occurred. When it did occur in these patients, renal failure may have been prevented as in Cases 21 and 22 by prevention of oligaemia through massive transfusion.

Haemoglobinuria only occurs when a considerable red cell volume is rapidly destroyed. This depends largely on the absolute skin area burned as well as the duration of burning. For equal percentage areas burned, children will lose a much smaller absolute volume of red cells than adults. Since children excrete a disproportionally (for body weight) larger volume of urine than adults, the urinary concentration of haemoglobin in children is likely to be considerably less than in adults. This may be responsible for the lower incidence of haemoglobinuria in Group 2 patients, all but one of whom were children, and for the higher incidence of haemoglobinuria in the Group 1 patients, all but one of whom were adults or adolescents.

Severe haemoglobinuria after burning may produce adverse renal effects in one or both of two ways. First, numerous casts may be precipitated in the distal tubules because of the reabsorption of water in the proximal tubules. Blockage by casts, particularly if renal ischaemia takes place. may be followed by tubular necrosis and rupture. Oliver et al. (1951) and Oliver (1953), who advocate the theory of "stopped pipes," have shown by the microdissection technique that local tubular blockage or rupture can interfere with the function of the whole nephron.

Secondly, severe haemoglobinuria denotes severe haemolysis. The loss of circulating red cells will not only add to the oligaemia due to loss of plasma but will cause a relative high haematocrit or haemoglobin value. If this is not taken into account the volume of lost plasma will be underestimated and as a result the patient may be undertransfused.

Oligaemia.-By almost general agreement renal ischaemia plays an important part in the pathogenesis of acute renal failure. In all severely burned patients there is inevitably an initial period of oligaemia which may last for hours due to the ․ㅡㄹ loss of a plasma-like exudate from the burned $\stackrel{\vec{F}}{\vec{F}}$ skin. The duration and degree of the oligaemia 0 will be determined by the rapidity and the volume 음 of plasma and blood transfused. Recent blood $\frac{\bar{s}}{\frac{}{\sigma}}$ volume studies suggest that most of the patients $\mathbb{\otimes}$ reported here had been oligaemic continuously or intermittently for varying periods (Topley, per- 2 sonal communication). The relationship of olig- $\vec{\circ}$ aemia to renal function in burned patients is now $\overrightarrow{\vec{\omega}}$ being studied.

\section{Summary}

A number of extensively burned patients in whom oliguria was slight or absent developed $\overrightarrow{\vec{N}}$ considerable azotaemia and acute uraemia. Most ${ }_{0}^{N}$ of them had haemoglobinuria. An injured patient $\stackrel{5}{工}$ also developed non-oliguric uraemia. All of them $\overrightarrow{7}$ died. and histologically the kidneys portrayed a $\mathbb{O}$ diffuse distal tubular necrosis (Lucké's lower nephron nephrosis). Clinically the non-oliguric form of acute uraemia is important to recognize $\vec{\theta}$ because of recent advances in therapy. Other $\mathcal{G}$ burned patients had histological evidence of a focal $\Omega$ form of distal tubular necrosis or the "healing "응 or " healed" residue of a recent attack. Neither oliguria nor uraemia had occurred, only a few of $\overline{0}$ them had had haemoglobinuria, and they died of non-renal complications. Renal function and $\stackrel{\square}{\complement}$ pathogenesis are discussed.

Thanks are due to various colleagues for their $\frac{3}{7}$ interest, to Dr. E. Topley for her co-operation on the problem of oligaemia. Dr. J. P. Bull and Miss S. Baar. F.R.I.C., for some of the biochemical data, $\mathrm{Mr}$.응 R. L. G. Dawson, Dr. D. Crockett, and Mr. I. E. K. Muir, of Mount Vernoun Hospital, for the additional 3 case report. to my secretary, Mrs. M. Swinden, and Mr. D. Gibb, A.I.M.L.T., who assisted with the photo-O micrography.

$$
\text { REFERENCES }
$$

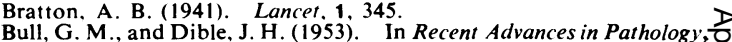
6th ed., edited by G. Hadfield, p. 284 . Churchill, London. Joekes, A. M., and Lowe, K. G. (1950). Clin. Sci., 9, 379 Bull, J. P., and England, N. W. J. (1954). Lancet, 2, 9.

Bywaters. E. G. L., and Beall, D. (1941). Brit. med. J., 1, 427.

- and Dible, J. H. (1942), J. Path. Bact., 54, 111.

Clark, E. J., Peters. R. A., and Rossiter, R. J. (1945). Quart. J. O exp. Physiol., 33, 113.

Dunn, J. S., Gillespie, M., and Niven, J. S. F. (1941). Lancet, 2. 549. $\omega$ Goodpastor, W. E., Levenson. S. M., Tagnon, H. J., Lund, C. C. O and Taylor, F. H. L. (1946). Surg. Gynec. Obstet., 82, 652.

Lucké, B. (1946). Milit. Surg., 99, 371.

Oliver, J. (1953). Amer. J. Med., 15, 535.

- MacDowell, M., and Tracy, A. (1951). J. clin. Invest., 30, 1305. \& Sevitt, S. (1951). Brit. med. J., 1, 976.

- (1954). Ibid.. 1, 541.

Shen. Shen, S. Chu, Ham, T. H., and Fleming, E. M. (1943). New Engl. J.
Med., 229, 701. Smith, H.W. (1951). The Kidney, p. 778. Oxford University Press, $\frac{\mathscr{D}}{\mathbb{D}}$
New York.

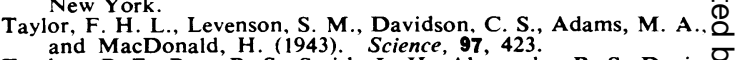

Teschan. P. E., Post, R. S., Smith, L. H., Abernathy, R. S., Davis $\underset{<}{\sigma}$ J. H., Gray, D. M., Howard, J. M., Johnson, K. E., Klopp, E.. Mundy, R. L., O’Meara, M. P., and Rush, B. F. (1955). Amer. O J. Med., 18, 172 . 